\title{
Multiple Electrosensory Maps in the Medulla of Weakly Electric Gymnotiform Fish. II. Anatomical Differences
}

\author{
Caroly A. Shumway \\ Neurobiology Unit, Scripps Institution of Oceanography, UCSD, La Jolla, California 92093
}

\begin{abstract}
Both wave- and pulse-type epecies of weakly electric gymnotiform fish have 3 topographic maps of electroreceptive information in the electrosensory lateral line lobe (ELL). These maps receive identical input from trifurcating axons of phaseand amplitude-coding primary afferents (Carr et al., 1982; Heiligenberg and Dye, 1982). Physiological experiments in the ELL of the wave-type fish Eigenmannia show that the amplitude-coding pyramidal cells differ among maps with respect to receptive field size, sensitivity, rate of adaptation, and temporal-frequency response (Shumway, 1989). This study investigated morphological correlates of the physiological differences among maps. Estimates of primary afferent convergence in Eigenmannia, based on map size, cell counts, and areas of terminal fields from intracellularly filled P-type primary afferents, suggest a 2-fold increase in convergence in the lateral map relative to the centromedial map. Similar differences in convergence between maps are found in the wave-type species Apteronotus leptorhynchus and the pulse-type fish Hypopomus occidentalis. The lateral and centrolateral maps in Hypopomus, however, show an even greater difference in convergence. Comparison of the efferent projections of pyramidal cells among the different maps of Eigenmannia indicates that cells from the 3 maps terminate in the same laminae of the torus semicircularis, but the maps differ in the strength of projection to particular laminae. In both wave-type species, the abundance of a class of interneurons which receives descending input and inhibits pyramidal cells (interneurons of the ventral molecular layer) differs among maps; the centromedial map has 10 times fewer neurons of this type than the other 2 maps. Cytochrome oxidase studies in all 3 species demonstrated increased levels of activity in the lateral map, within the region receiving descending input from the cerebellum. These results suggest that the primary anatomical bases of the physiological differences among maps are differences in the amount of primary afferent convergence, coupled with differences in descending input.
\end{abstract}

\footnotetext{
Received Oct. 31, 1988; revised May 31, 1989; accepted June 5, 1989.

This work was supported by National Institutes of Mental Health grant 2-RO1MH-26149 to Walter Heiligenberg. Many thanks to Margaret Leong and Grace Kennedy for their technical assistance with the extracellular HRP processing, and to Benedicte Callan for her help in analysis of the primary afferent terminal fields. I thank Walter Heiligenberg, T. H. Bullock, Jim Enright, and the anonymous reviewers for helpful criticism of this manuscript.

Correspondence should be addressed to Caroly A. Shumway, Division of Biology, California Institute of Technology, 1201 E. California Boulevard, Pasadena, CA 91125 .

Copyright (c) 1989 Society for Neuroscience $0270-6474 / 89 / 124400-16 \$ 02.00 / 0$
}

Multiple cortical sensory maps in a variety of mammals exhibit both similarities and differences. The similarities are believed to reflect common ancestry as well as general principles of mammalian sensory processing, and the differences reflect sensory specializations of each animal: (1) Although all nonprimate mammals have one complete somatosensory representation in area S1 "proper," several species have duplicate representations of body parts containing a high density of somatosensory receptors: gray squirrels have a dual forepaw representation (Sur et al., 1982); rabbits have a dual representation of the pinna of the ear (Gould, 1986); and opossums have a dual representation of the vibrissae (Pubols et al., 1976). (2) The somatotopy of area $\mathrm{S} 1$ in most mammals is remarkably consistent. Bats, however, have a reorganized representation of the digits in S1 relative to other mammals; the representation of the forelimb digits, which comprise the structural elements of the wing, are directed caudally, in contrast to the rostral representation found in a variety of mammals. The difference in orientation of the digits represented in area $S 1$ of bats corresponds to the different postural relationship of the digits relative to other body parts (Calford et al., 1985).

All weakly electric gymnotiform fish have 4 maps of electrosensory information from the body surface at the level of the first-order nucleus, the electrosensory lateral line lobe, or ELL (Carr et al., 1982; Heiligenberg and Dye, 1982); 3 maps (lateral, centrolateral, and centromedial) receive high-frequency, tuberous electroreceptive input, while 1 map (medial) receives lowfrequency, ampullary electroreceptive input. The medial map will not be discussed further. Gymnotiform species can be classified into 2 different groups based on the pattern of their electric organ discharges, or EODs: wave-type species, which produce nearly sinusoidal EODs, and pulse-type species, which produce very brief pulses separated by long and variable intervals. The differentiation of the EOD in these 2 groups is reflected to some extent by corresponding neural specializations in the processing of electric signals (see Heiligenberg, 1986; Zakon, 1986; Shumway and Zelick, 1988). Since both types of fish have multiple tuberous maps in the ELL, these maps are likely to be important in common aspects of electrosensory processing. This does not, however, preclude the possibility of structural and functional specializations within the multiple maps of the 2 types of electric fish. These multiple maps have been studied in the wave-type fish Eigenmannia and are intriguing in that they receive apparently identical primary afferent input; they contain similar output neurons and interneurons; and there are no known intermap connections (Heiligenberg and Dye, 1982; Carr and Maler, 1986). Axonal collaterals from phase- and amplitude-coding primary afferents (T- and P-type, respectively) project to all 3 
maps. T-type afferents synapse onto spherical cells. P-type afferents provide input to 2 physiologically distinct types of pyramidal cells: E cells, or basilar pyramidal cells, which receive direct afferent inputs and are excited by a rise in stimulus amplitude, and I cells, or nonbasilar pyramidal cells, which receive indirect afferent input through inhibitory granule cells and are excited by a fall in stimulus amplitude (Maler, 1979; Saunders and Bastian, 1984).

Physiological comparison of the tuberous maps in Eigenmannia has demonstrated that the amplitude-coding pyramidal cells differ among maps in a number of spatial and temporal response properties (Shumway, 1989). On average, pyramidal cells in the lateral map have large receptive fields, are most sensitive, respond phasically to a step change in stimulus amplitude, and respond to high frequencies of amplitude modulation. Pyramidal cells in the centromedial map have small receptive fields, respond in a more sustained fashion to a step change in amplitude, and nearly half of the cells show a lowpass temporal frequency response. Cells in the centrolateral map have properties intermediate to those in the other 2 maps. This study explored anatomical properties of the maps in 2 wavetype and 1 pulse-type species in order to identify morphological correlates of the physiological differences. Morphological differences among the maps were characterized by a combination of techniques-intracellular and extracellular HRP and Lucifer yellow injections, cell counts from Nissl sections, and cytochrome oxidase studies.

Preliminary versions of these results have been reported in abstract form (Shumway, 1984, 1986).

\section{Anatomical background}

The ELL is a medullary nucleus with 6 laminae and 11 cell types (see Maler, 1979; Carr and Maler, 1986, for more details). The ascending projection neurons of the tuberous maps in the ELL are the amplitude-coding basilar and nonbasilar pyramidal cells, located in the pyramidal cell lamina, and the phase-coding spherical cells, located in the deep neuropil lamina. All other cell types in the tuberous maps of the ELL are involved in the amplitude-coding circuit; the most important cell types for shaping the response properties of pyramidal cells are the inhibitory granule cell interneurons 1 and 2 (Maler et al., 1981; Shumway and Maler, 1989). Polymorphic cells, ovoid cells, and neurons of the ventral molecular layer also provide inhibitory synaptic inputs to pyramidal cells; the first 2 cell types also project to the contralateral ELL (Maler et al., 1982; L. Maler, unpublished observations).

Major afferent and efferent connections to and from the tuberous segments of the ELL in wave-type fish are schematized in Figure 1. For further details, see Carr and Maler (1986). Ascending projections of the ELL lead to 2 midbrain structures, the torus semicircularis and the nucleus praeeminentialis. Phase and amplitude information from the ELL reaches the dorsal torus semicircularis via the lateral lemniscus (Carr et al., 1981; Carr and Maler, 1985). Spherical cells from all 3 maps converge onto a single body map in lamina 6 of the contralateral torus semicircularis. Large HRP injections suggest that pyramidal cell efferents from all maps also converge onto a single body map in the contralateral torus semicircularis, terminating in lamina 3, 5, 7, 8c, 8d, and occasionally 9 (Carr et al., 1981; Maler et al., 1982). In contrast to spherical cells, pyramidal cells also send collaterals to the contralateral nucleus praeeminentialis dorsalis pars principalis (NPd), an isthmic structure composed

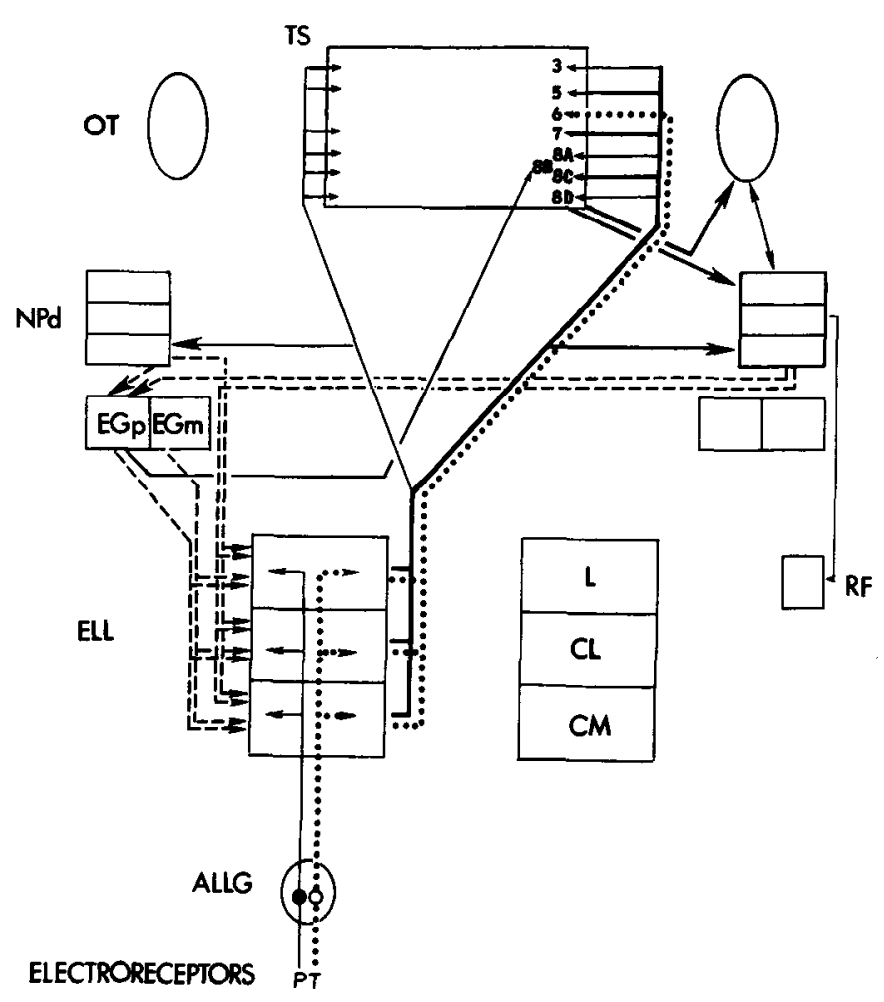

Figure 1. Schematic of the major afferent and efferent connections of the tuberous maps in the ELL. See text for explanation. Thick lines represent major projections; dashed lines indicate both direct and indirect descending projections to the ELL. Projections of pyramidal cells in the ELL to the torus semicircularis are represented by the solid line, while the projections of the phase-coding spherical cells are represented by the dotted line. Abbreviations: $A L L G$, anterior lateral line nerve ganglion; $E G p$, eminentia granularis posterior; $E G m$, eminentia granularis medialis; $N P d$, nucleus praeeminentialis dorsalis; $T S$, torus semicircularis; $O T$, optic tectum; $R F$, reticular formation; $L$, lateral map of the ELL; $C L$, centrolateral map of the ELL; $C M$, centromedial map of the ELL; $P$, P-type electroreceptors encoding amplitude information of the EOD; $T$, T-type electroreceptors encoding phase information of the EOD.

of 3 anatomical zones. Pyramidal cells in the 3 ELL maps project in a map-specific manner to these zones (Maler et al., 1982; Sas and Maler, 1983); the lateral map in the ELL projects to the dorsal map in the NPd; the centrolateral map projects to the upper central zone; and the centromedial map projects to the lower central zone. The separation of processing in the ELL maps, therefore, is maintained in the nucleus praeeminentialis. Note that the nucleus praeeminentialis receives only amplitude information from the ELL. Moderate ipsilateral ELL-torus semicircularis and ELL-nucleus praeeminentialis dorsalis are also present; the functional significance of these ipsilateral projections is still unknown.

As in the auditory system, the ELL receives extensive feedback through descending, recurrent loops. A major descending input to the ELL arises from cells in both the contra- and ipsilateral NPd which synapse onto the proximal portion of the apical dendrites of pyramidal cells, as well as onto the apical dendrites of several interneurons in the ventral molecular layer (including granule cells type 2, polymorphic cells, and the neurons of the ventral molecular layer). A second major recurrent path originates from both NPds via the ipsilateral posterior eminentia granularis (EGp); the EGp provides synaptic inputs 
to the more distal portions of the apical dendrites of the abovementioned ELL cells in the dorsal molecular layer of the ELL. The medial eminentia granularis (EGm) also projects to the more distal portions of the apical dendrites, although this information is not believed to be electrosensory (Sas and Maler, 1987).

Several higher-order connections produce more complicated feedback loops. The torus semicircularis provides a major input to the NPd. The torus semicircularis also projects to the optic tectum, which has reciprocal connections with the NPd. Both pathways can potentially provide phase information to the NPd. The EGp projects to laminae $8 \mathrm{~b}$ of the torus. Although it has no reciprocal connections with the torus semicircularis, the EGp can be influenced by the torus semicircularis via the NPd.

\section{Materials and Methods}

Extracellular injections of HRP. Fish of the genus Eigenmannia, 10$15 \mathrm{~cm}$ long, were anesthetized with a solution of tricaine methane sulfonate (MS222). The experimental tank and surgical techniques were similar to those described in the preceding paper (Shumway, 1989). The appropriate depth for HRP injection was determined physiologically, using platinum-plated indium electrodes for recording (Frank and Becker, 1964). The electrical stimulus was an amplitude-modulated sine wave (similar in frequency to the animal's EOD prior to anesthesia) which was applied via silver-wire electrodes in the mouth and near the tail. HRP electrodes $(10-15 \mu \mathrm{m}$ tip diameter, $30-50 \mathrm{M} \Omega)$ were filled with a $10 \%$ solution of HRP in a pH 7.4 Tris buffer. HRP was injected iontophoretically at the appropriate depth for 4-10 min, using 1-4 $\mu \mathrm{A}$ of positive current. After survival times of 3-4 d, the fish was deeply anesthetized with MS222 and perfused with $4 \%$ paraformaldehyde in a $0.1 \mathrm{M}$ phosphate buffer, $\mathrm{pH}$ 7.4. Brains were processed for peroxidase activity, using the DAB glucose-oxidase procedure (Metcalfe, 1985). Thirteen injections were made in the ELL: 3 in the centromedial map, 5 in the centrolateral map, and 5 in the lateral map. Five injections were made in the torus semicircularis, and 11 additional torus semicircularis injections were available from a previous study (Carr et al., 1981).

Intracellular injection of HRP or Lucifer yellow. Thirty-four pyramidal cells were intracellularly filled with HRP or Lucifer yellow. Electrodes were pulled on a Brown-Flaming micropipette puller (typical impedance, $60-200 \mathrm{M \Omega}$ ) and were filled with either a $2-10 \%$ solution of HRP in $0.5 \mathrm{M} \mathrm{KCl}$ and $0.1 \mathrm{M}$ Tris buffer, $\mathrm{pH} 7.4$, or a $20-25 \%$ solution of Lucifer yellow in $0.1 \mathrm{M} \mathrm{LiCl}$. Neurons were filled for $10-25 \mathrm{~min}$ by iontophoretic injection of a $2-4 \mathrm{nA}, 3 \mathrm{~Hz}$ sinusoidal current, offset from DC by the appropriate polarity (positive for HRP, negative for Lucifer yellow). Thirteen cases of intracellular injections of P-type primary afferents were available from a previous study (Heiligenberg and Dye, 1982).

Cell counts. Cells were counted in $40 \mu \mathrm{m}$ serial sections of normal material, and in every available section. No correction was made for split nucleoli (Konigsmark, 1970). The relative abundance of granule cells was determined by tracing the granule cell layer of each map from representative sections with a camera lucida, followed by cutting out and weighing of the map area. Statistical procedures used to compare measurements from the 3 maps were a parametric ANOVA, followed by multiple comparison testing with a Tukey test. In both cases, the alpha level was set at 0.05 . All measures of variability are SDs.

Cytochrome oxidase. Five Eigenmannia sp., 2 Apteronotus leptorhynchus, and 3 Hypopomus occidentalis were used. Animals were anesthetized with MS222 and were perfused with a $2 \%$ paraformaldehyde$1 \%$ glutaraldehyde solution. Brains were reacted for cytochrome oxidase activity, according to the procedure of Wong-Riley (1979). Briefly, the brain was cut in $100 \mu \mathrm{m}$ transverse sections with a Vibratome, and the sections were then incubated with $50 \mathrm{mg} \mathrm{DAB}, 90 \mathrm{ml} 0.1 \mathrm{M}$ phosphate buffer, $\mathrm{pH} 7.4$, and $30 \mathrm{mg}$ cytochrome $\mathrm{C}$ for $2-3 \mathrm{hr}$ in the dark at $37^{\circ} \mathrm{C}$, followed by 3 rinses in phosphate buffer. Sections were qualitatively examined for possible differences in cytochrome oxidase activity among maps. The predominant difference, a varying level of activity in the dorsal molecular layer, was analyzed by measuring the relative levels of cytochrome oxidase activity within the dorsal molecular layer of each map with the spot meter of a Zeiss photomicroscope (at $200 \times$ total magnification). At least 5 sections were examined per fish. For each section, the light level was adjusted to produce a constant reading of the cytochrome oxidase activity in the dorsal molecular layer of the lateral map. The amount of light transmitted through the dorsal molecular layer in the other 2 maps from the same section was then measured in reference to the fixed value of that of the lateral map. The inverse of this index of transmitted light provides a measure of relative optical density for each map; the ratio of these values was then calculated for comparisons of cytochrome oxidase activity between maps.

\section{Results}

Map size

As background for interpreting the present results, Figure $2 \mathrm{~A}$ illustrates the somatotopic organization of the fish's body surface within the 3 tuberous maps in Eigenmannia (figure modified from Heiligenberg and Dye, 1982). The "pisciculi" (i.e., "little fish") in all maps show a magnification of the representation of the head, which has the greatest density of tuberous electroreceptors (Carr et al., 1982). Adjacent maps are mirror images of each other: the centromedial segment maps the dorsoventral body axis lateromedially; the centrolateral segment maps the same axis mediolaterally; and the lateral segment shares the same orientation as the centromedial segment. The rostrocaudal axis in all maps forms an angle of $45^{\circ}$ with that of the body (Carr et al., 1982). Figure 2, $B, C$ shows the anatomical organization of the tuberous maps in a transverse section from the wave-type electric fish Eigenmannia sp. and the pulse-type fish Hypopomus occidentalis, respectively. Borders between maps can be recognized as distinct cytoarchitectonic breaks (arrowheads) in the 2 main cell layers, pyramidal and granule. The more dorsal pyramidal lamina includes basilar pyramidal cells, nonbasilar pyramidal cells, and polymorphic cells, while the granule cell lamina includes granule cells types 1 and 2, and a sublamina of spherical cells (Maler, 1979).

Figure 2, B, C shows that the maps differ in size in both waveand pulse-type species, with the lateral map being the smallest. The 2 species differ, however, in the ranking of relative size between centromedial and centrolateral maps; the centromedial map is largest in wave-type fish (also see Maler, 1979; Carr et al., 1982), while the centrolateral map is largest in pulse-type fish.

Tuberous map sizes were measured for 6 species from 4 different families, using $40 \mu \mathrm{m}$ serial sections of Nissl material (Table 1). The width of the pyramidal cell layer within each map was measured for each transverse section; the sum of these values multiplicd by the thickness of the sections provided the map area. The average rostrocaudal and mediolateral dimensions of the maps in 18 Eigenmannia specimens, ranging in size from 9 to $13 \mathrm{~cm}$, were $870 \times 892 \mu \mathrm{m}(\mathrm{CM}$ map); $773 \times 578$ $\mu \mathrm{m}$ (CL map); and $652 \times 407 \mu \mathrm{m}$ (L map). As shown in Table 1 , the area of the centromedial map in Eigenmannia and $A p$ teronotus is roughly 2.5 times as large as the area of the lateral map, and the area of the centrolateral map is 1.7 times as large. All pairwise comparisons between maps are significantly different for these 2 species, as judged by a Tukey test. For the 3 species of pulse-type fish in the family Hypopomidae, the area of the centrolateral map is $3-4$ times as large as that of the lateral map, and the ratio between centromedial map and lateral map areas ranges from 1.5 to 3 . Only the difference between the centrolateral and the lateral map is significant, as measured for 3 specimens of Hypopomus occidentalis. The centromedial and centrolateral maps from a single specimen of the pulse-type fish Gymnotus carapo (family Gymnotidae) were of the same size. 

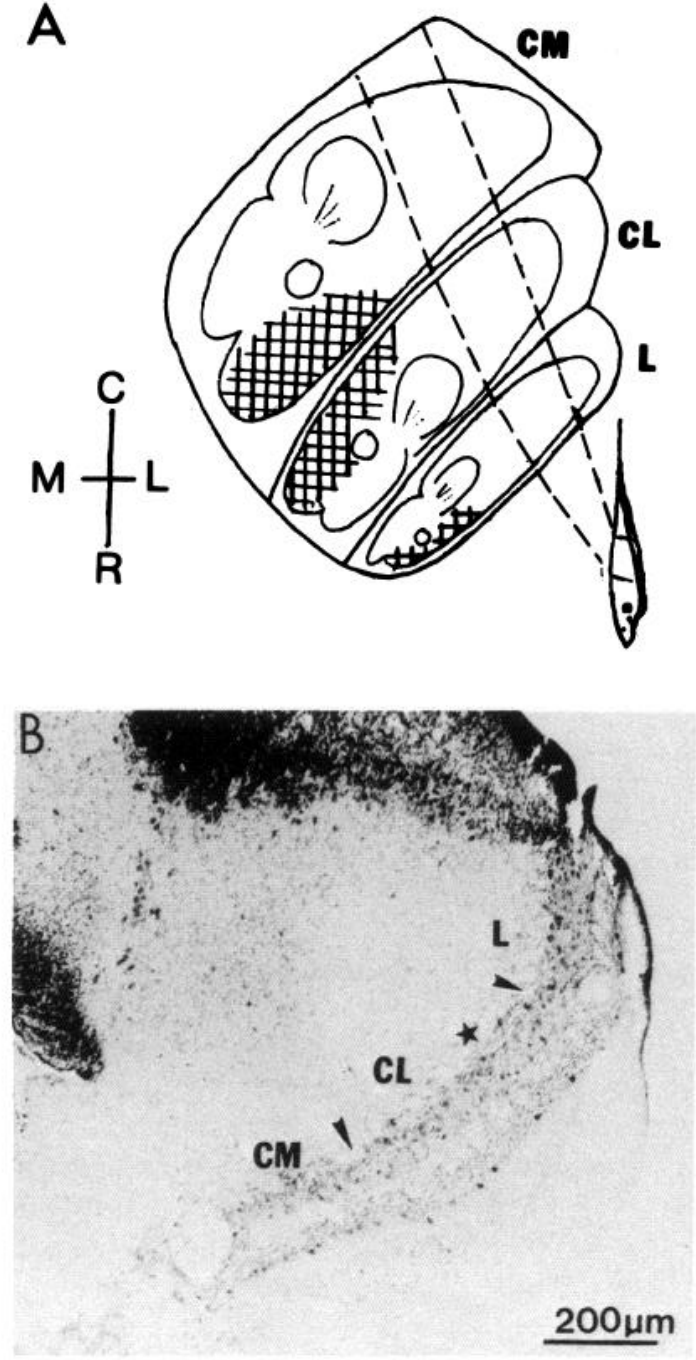
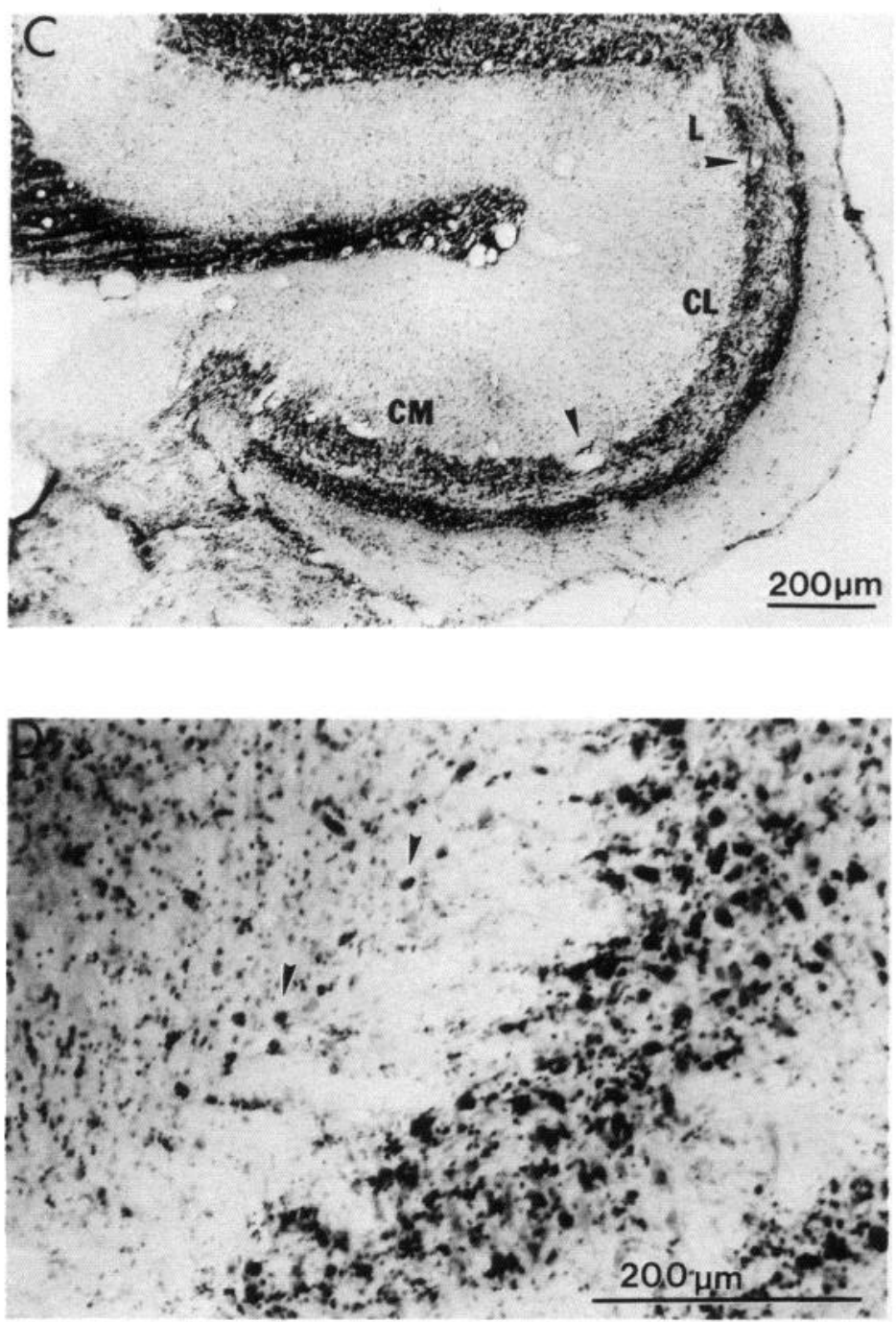

Figure 2. Physiological and anatomical topography of the 3 ELL tuberous maps in the ELL. A, Schematic of the somatotopic representation of the fish's body surface within each of the 3 maps, as determined by intracellular recording and filling of primary afferents in Eigenmannia (figure modified from Heiligenberg and Dye, 1982). Cross-hatchings represent the part of the head above water, where no receptors could be recorded for technical reasons. $B$ and $C$, Low-power photomicrographs of a transverse section through the ELL in the wave-type fish Eigenmannia sp. $(B)$ and the pulse-type fish Hypopomus occidentalis (C), showing the cytoarchitectonic breaks between maps (arrowheads). $L$, lateral map; $C L$, centrolateral map; $C M$, centromedial map. Scale bar, $200 \mu \mathrm{m}$. Star in $B$ indicates the sublayer of neurons of the ventral molecular layer located above the major cell layers. $D$, High-power photomicrograph of the neurons of the ventral molecular layer (arrowheads) in Eigenmannia. Scale bar, $200 \mu \mathrm{m}$.

Table 1. Mean area \pm SD of the 3 ELL maps in 6 different species of gymnotoid fish from 3 different families

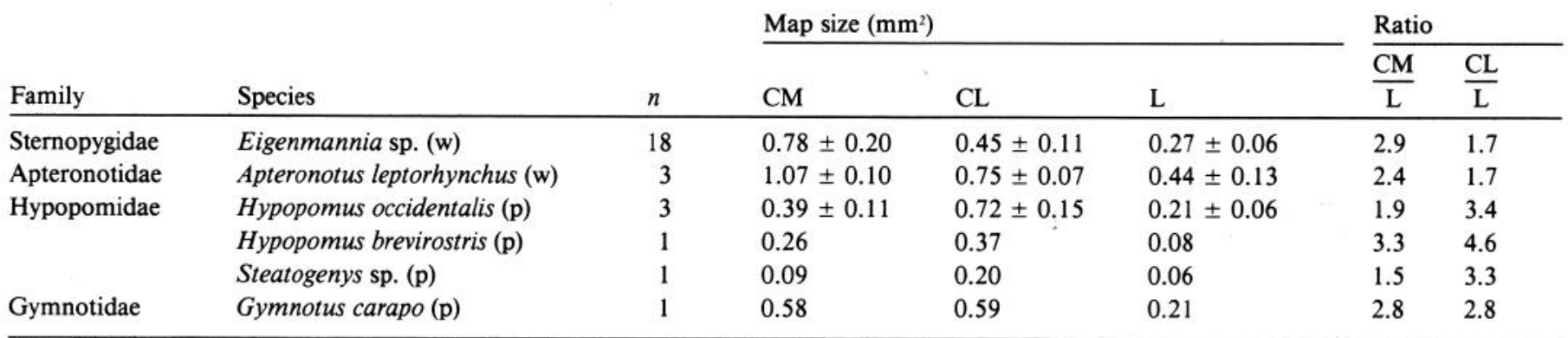

(w) and (p) indicate wave-type and pulse-type fish, respectively. $n$, number of fish. The centromedial map is largest in wave-type fish, while the centrolateral map is the largest in most pulse-type fish. The centromedial and centrolateral maps are equal in size in the pulse fish Gymnotus carapo. All pairwise comparisons between maps are significantly different for Eigenmannia and Apteronotus, while only the centrolateral and lateral map areas differed significantly in Hypopomus occidentalis. 
A

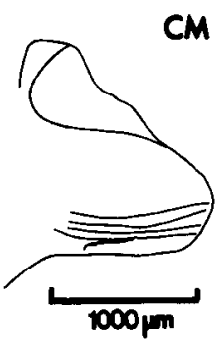

B

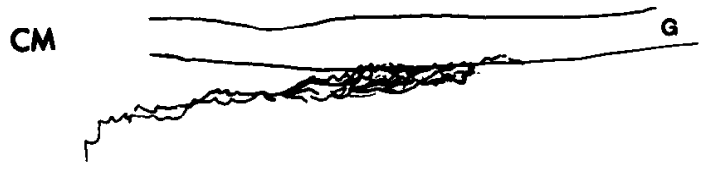

$\mathrm{Cl}$

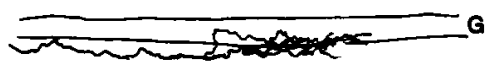

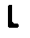

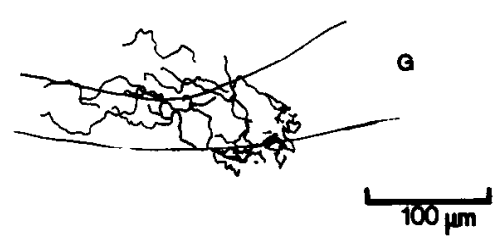

C

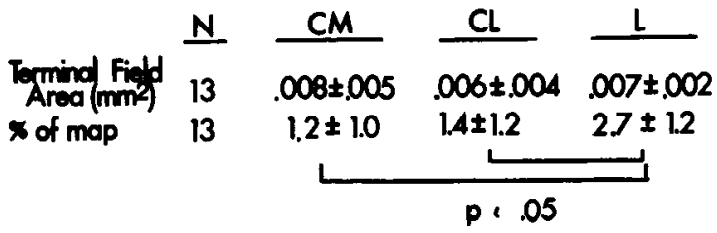

Figure 3. $A$ and $B$, Camera lucida drawings of the terminal fields of a single HRP-filled P-type primary afferent in each of the 3 ELL maps, traced from transverse sections. $A$, Low-power tracing indicating the terminal field orientation within each map. $B$, Higher-power tracings of the terminal field within each map, oriented in the same way for comparison. $G$, Granule cell lamina. $C$, Top: Mean area $\pm \mathrm{SD}$ of the primary-afferent terminal fields in each map. Mean areas were not significantly different among maps. Bottom: Mean percentage \pm SD of the extent of map covered by the terminal fields. Measured in this fashion, the lateral map values differ significantly from those of the other maps.

\section{Intracellular fills of $P$-type primary afferents}

Intracellular HRP fills of 13 P-type primary afferents from 13 fish were used to compare the extent of afferent terminal arborizations among the 3 maps (Fig. 3). As illustrated by the camera lucida tracing of an afferent in Figure $3 B$ and as summarized in Figure $3 C$, the area of the terminal fields did not significantly differ among maps. Average rostrocaudal and mediolateral dimensions of the terminal field in all maps were approximately $115 \times 60 \mu \mathrm{m}$. Since the areas of the maps differ, however, primary afferent terminal fields extend over relatively larger portions of the lateral map and relatively smaller portions of the other 2 maps. The percentage of each map covered by individual terminal fields is $2.7 \%$ for the lateral map; $1.4 \%$ for the centrolateral map; and $1.3 \%$ for the centromedial map (Fig. $3 C$ ). The lateral map values differ significantly from those of the other maps $(p<0.05)$.

\section{Cell counts in the ELL}

Counts of the main cell types in the ELL indicate that the numbers of most types of cells reduce gradually in a mediolateral progression through the ELL, with roughly a 2-fold decrease in number between the centromedial and lateral maps (Table 2). Thus, map area and cell number are positively correlated; the centromedial map has the largest area and contains the greatest number of cells. Since the abundance of most types of interneurons relative to that of pyramidal cells is similar across maps, this suggests that the local ELL circuits within the maps do not differ dramatically. (This does not preclude the likely possibility that synaptic connections will be found to differ among maps, either in abundance or relative position.) One type of inhibitory interneuron, however, did not follow such a pattern. The neurons of the ventral molecular layer occurred in equal numbers in the centrolateral and lateral maps, whereas one-tenth that number was found in the centromedial map. As previously mentioned, neurons of the ventral molecular layer receive descending input from the nucleus praeeminentialis dorsalis and the EGp (Maler et al., 1981). They also receive input from polymorphic and granule cells and they provide GABAergic input to pyramidal cells, polymorphic cells, and granule cells ( $\mathrm{L}$. Maler, personal communication). A similar difference was found in the number of neurons of the ventral molecular layer among maps in Apteronotus (179 \pm 32 in the lateral map; $173 \pm 22$ in the centrolateral map; $10 \pm 8$ in the centromedial map; $n=$ 2; also see Maler, 1979).

The diameter of 50 pyramidal and spherical cell somata within each map was measured for a single fish. Pyramidal cell somata were approximately of the same size in all maps (average of $10 \mu \mathrm{m}$ ), while spherical cell somata were somewhat smaller in the centromedial map (12 vs. $15 \mu \mathrm{m}$ in the remaining maps). As noted by Maler (1979), this implies that the size of spherical cells decreases as their density increases.

\section{Pyramidal cell morphology}

Intracellular fills of 34 pyramidal cells in Eigenmannia with Lucifer yellow or HRP demonstrated that basilar and nonbasilar pyramidal cells had a local axonal collateral and that the presence of this collateral varied among maps: 9 out of 10 pyramidal cells in the centromedial map had collaterals, 6 out of 12 in the centrolateral map had collaterals, and none of 12 in the lateral map had collaterals (Fig. 4; these 3 cells are from different fish). The collateral typically branched $50-100 \mu \mathrm{m}$ from the soma and was so fine that its termination could be traced in only 2 wellfilled HRP cases (Fig. 4, centrolateral and centromedial cells). The collateral of the cell in the centrolateral map terminated near the granule cell layer. The collateral of the cell in the centromedial map terminated in the vicinity of the basilar dendrite of the basilar pyramidal cell. A secondary branch of the collateral was seen but was too faint to follow. The synaptic connections of the collateral are unknown. Axonal collaterals were not found on pyramidal cells in Apteronotus (Maler, 1979; Saunders and Bastian, 1984).

As illustrated by the cells in Figure 4, the apical and basilar dendrites of the pyramidal cells showed considerable variability in shape and distribution (also see Maler, 1979), but neither the apical nor the basilar dendrites of pyramidal cells appeared to vary in any systematic way among maps. This issue needs to be reexamined with a larger sample of intracellularly labeled cells and with comparison of Golgi material. Saunders and Bas- 

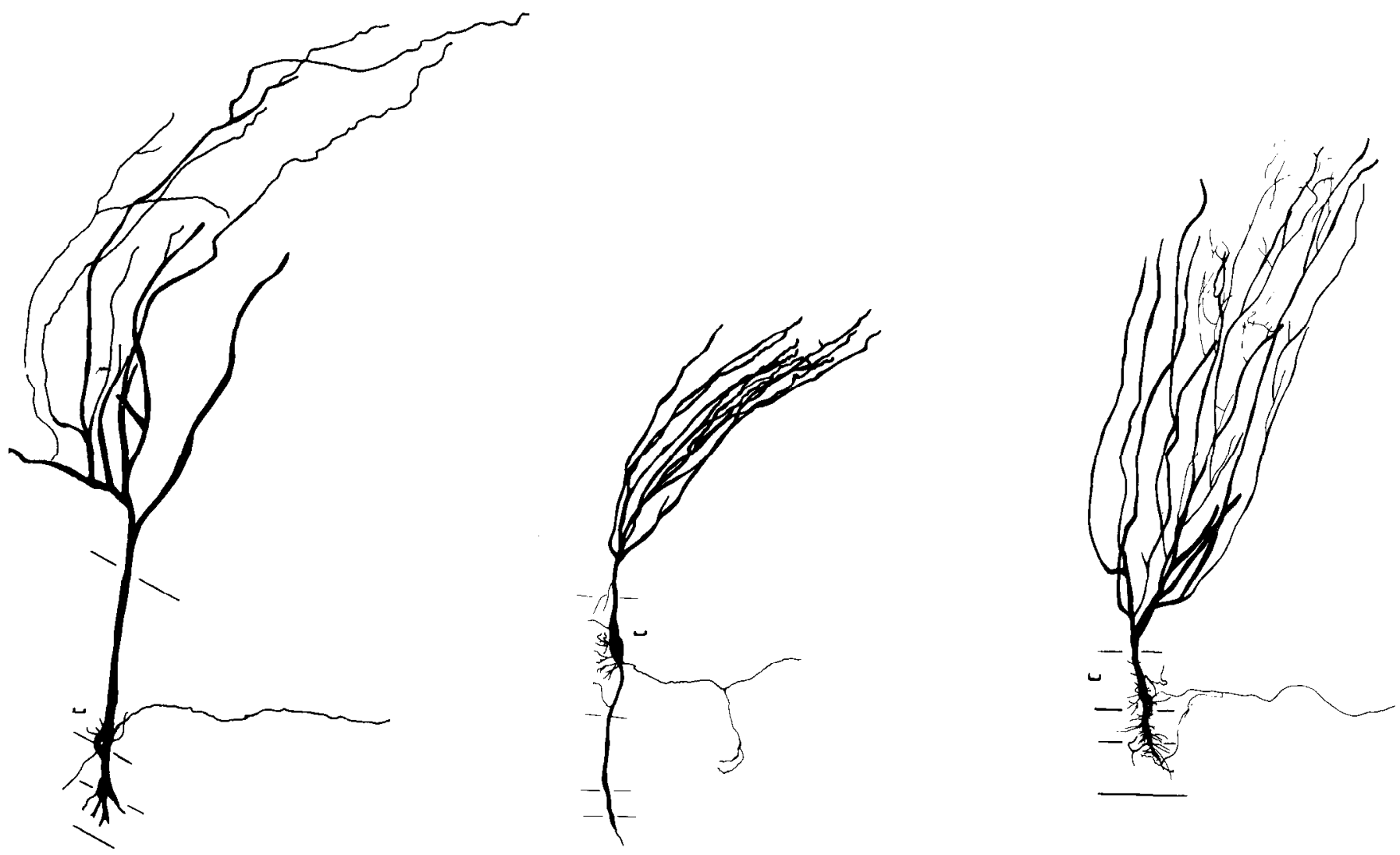

Figure 4. Camera lucida tracings of basilar pyramidal cells from the 3 maps. Each cell is from a different fish. Cells in the centromedial and centrolateral map have a local axonal collateral not present in cells of the lateral map. Scale bars, $20 \mu \mathrm{m}$.

tian (1984) also found no morphological differences in the apical dendrites of HRP-filled pyramidal cells between the lateral and centrolateral maps of Apteronotus.

Pyramidal cell projections from the tuberous maps to the torus semicircularis

As the tuberous maps have been shown to differ physiologically with respect to receptive field size, threshold sensitivity, rate of adaptation, and temporal-frequency response of their pyramidal neurons (Shumway, 1989), it is important to know whether their efferent projections to the torus semicircularis also differ. Three different approaches were used to address this question: small extracellular HRP injections in individual maps of the ELL, intracellular HRP and Lucifer yellow injections of pyramidal cells, and small extracellular HRP injections in single laminae of the torus semicircularis.

Thirteen small HRP injections (200-300 $\mu \mathrm{m}$ wide, labeling from 6 to 20 pyramidal cells) were made in the tuberous maps of the ELL: 5 in the lateral map, 5 in the centrolateral map, and 3 in the centromedial map. Pyramidal cells from all 3 maps projected to laminae $3,5,7,8 \mathrm{c}$, and $8 \mathrm{~d}$ of the torus semicircularis, as previously described by Carr et al. (1981) and Maler et al. (1982). Projections were weakest to lamina 3. Some afferents continued through lamina 1 , decussating and projecting to the other side via what Scheich and Ebbesson (1983) term the "supratoral decussation."

In all cases, the maps differed in the strength of projection to a given lamina (Figs. 5, 6A). Centromedial map efferents did not project hcavily to lamina $8 \mathrm{~d}$ (Fig. $5 A$ ); centrolateral map efferents did not project heavily to lamina 7 (Fig. $5 B$ ); and lateral map efferents projected bilaterally to lamina 5 (Fig. $5 C$ ). Although the densest arborization of lateral map efferents in lamina 5 was in somatotopic register with their terminal fields in other laminae, fine terminal swellings of lateral map efferents were found throughout much of the lamina. As shown for the lateral map efferents in Figure $5 D$, the mediolateral extent of the terminal field in lamina 7 was approximately $50 \mu \mathrm{m}$, while the extent in lamina 5 was over $400 \mu \mathrm{m}$. Large extracellular HRP injections in the ELL by Scheich and Ebbesson (1983) also demonstrated bilateral arborization in laminae 5 , but injections were not restricted to a single map. Centromedial map efferents projected most heavily to lamina 7 . One other difference was found among efferent projections from the maps: axons of pyramidal cells from the lateral map often had unusually large varicosities (average size $5 \mu \mathrm{m}$ ), less commonly seen in efferents from the centrolateral map and rarely seen in efferents from the centromedial map (examples, Figs. $5 D, 6 B$ ). These varicosities were found in laminae $5,7,8 \mathrm{c}, 8 \mathrm{~d}$, and in the vertical neuropil of lamina 6 . Electron microscopic examination will be necessary to determine whether such varicosities are en passant synaptic endings.

Finally, these HRP injections suggested that the maps may differ in the abundance of a rare, large cell type: the giant fusiform cell. These cells looked similar to those described by Maler (1979), which had 2-3 large apical dendrites and thick dendrites ramifying in the pyramidal cell layer. Six of such 

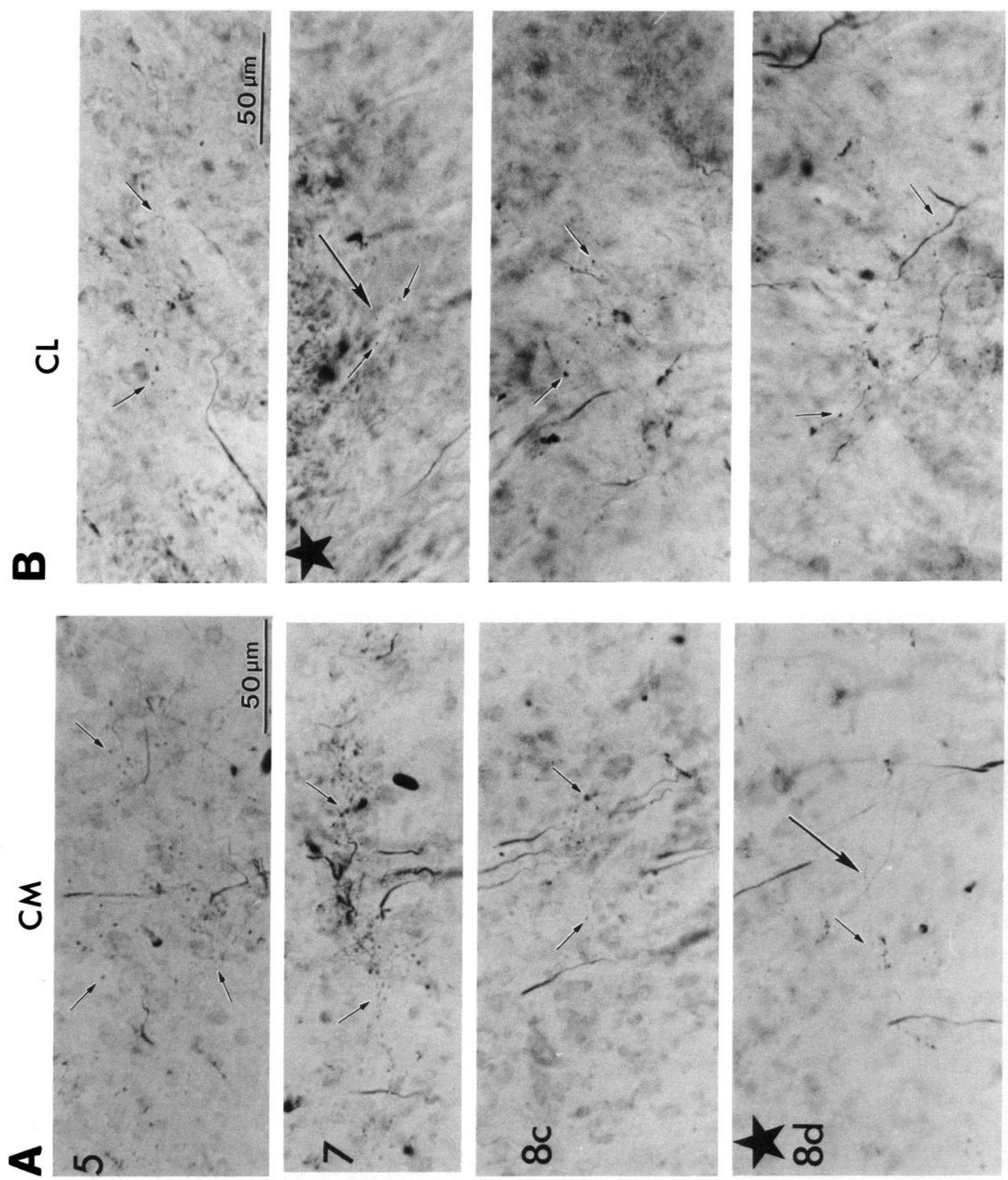

Figure 5. A-C, Photomicrographs of pyramidal-cell terminal fields (small arrows) in different laminae of the torus semicircularis. Stars and large arrows indicate the main differences in projections from the 3 maps. Scale bar, $50 \mu \mathrm{m}$. D. Top: Low-power photomicrograph demonstrating the extensive terminal-field arborization in lamina 5 from pyramidal cells of the lateral map. Numbers indicate identity of the lamina. Note the 

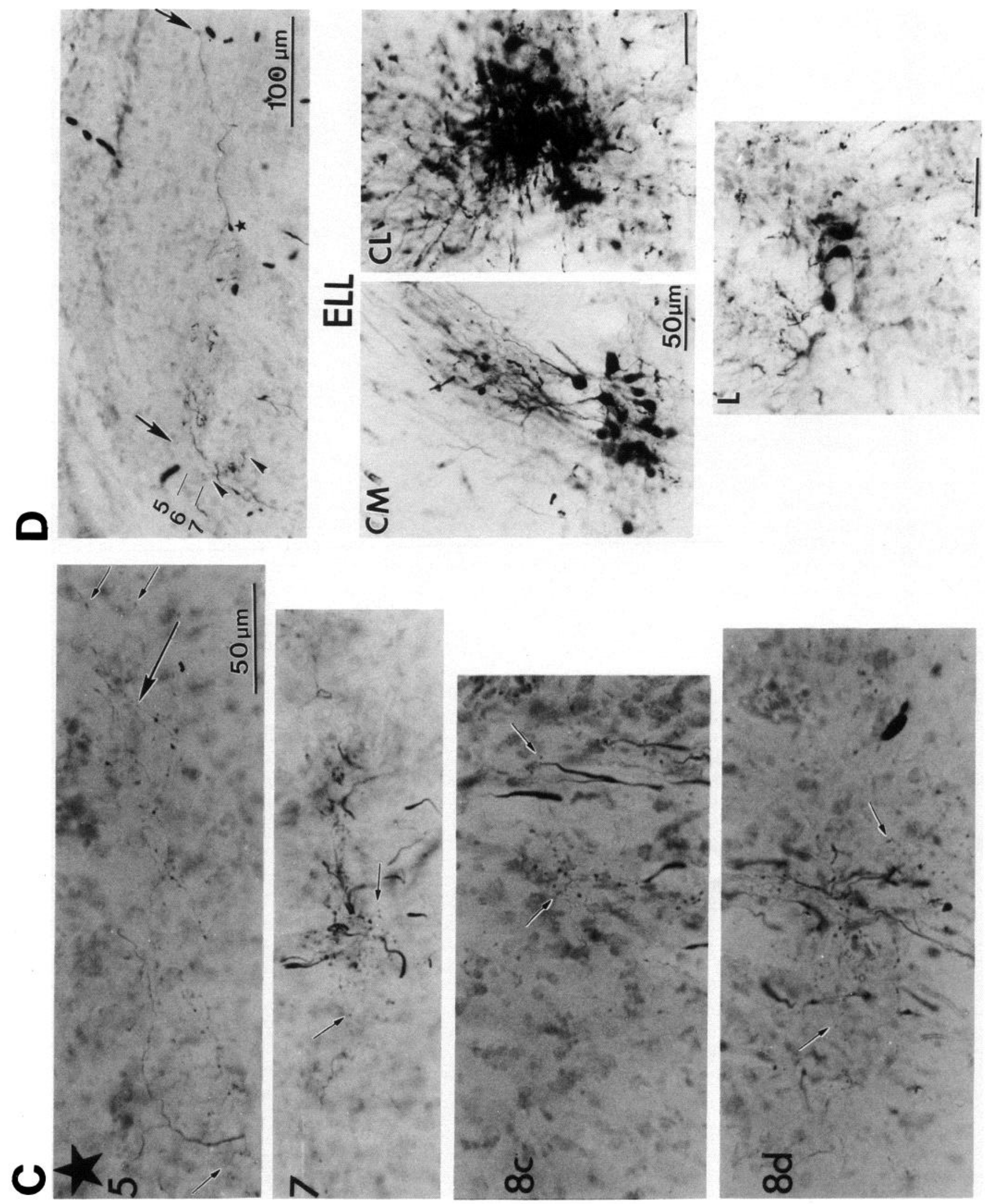

difference in extent of the projections in lamina 5 (arrows) and 7 (arrowheads), and the large varicosity in lamina 5 (star). Scale bar, $100 \mu \mathrm{m}$. Bottom: Injection sites in the ELL; each HRP injection was confined to a single map. Scale bar, $50 \mu \mathrm{m}$. 
Table 2. Mean cell number \pm SD of the major cell types in the 3 ELL maps

\begin{tabular}{|c|c|c|c|c|c|c|c|c|}
\hline \multirow[b]{2}{*}{ Cell type } & \multirow[b]{2}{*}{$n$} & \multirow[b]{2}{*}{$\mathrm{CM}$} & \multirow[b]{2}{*}{$\mathrm{CL}$} & \multirow[b]{2}{*}{ L } & \multirow{2}{*}{$\begin{array}{l}\text { Ratio } \\
\frac{\mathrm{CM}}{\mathrm{L}}\end{array}$} & \multicolumn{2}{|c|}{ Significance } & \multirow[b]{2}{*}{$\frac{\mathrm{CM}}{\mathrm{CL}}$} \\
\hline & & & & & & $\frac{\mathrm{CM}}{\mathrm{L}}$ & $\frac{C L}{L}$ & \\
\hline Pyramidal & 3 & $1425 \pm 290$ & $1189 \pm 176$ & $690 \pm 202$ & 2.1 & $*$ & & \\
\hline Spherical & 6 & $277 \pm 126$ & $105 \pm 55$ & $81 \pm 40$ & 3.4 & $*$ & & $*$ \\
\hline Polymorphic & 6 & $365 \pm 72$ & $313 \pm 87$ & $211 \pm 59$ & 1.7 & $*$ & $*$ & \\
\hline $\mathrm{N}$ of the VML & 5 & $10 \pm 8$ & $100 \pm 37$ & $95 \pm 35$ & 0.11 & $*$ & & $*$ \\
\hline Multipolar & 3 & $134 \pm 13$ & $97 \pm 7$ & $69 \pm 9$ & 1.9 & $*$ & $*$ & $*$ \\
\hline Ovoid & 5 & $49 \pm 26$ & $42 \pm 11$ & $31 \pm 12$ & 1.6 & & & \\
\hline Granule $^{a}$ & 2 & $1212 \pm 93$ & $882 \pm 117$ & $760 \pm 43$ & 1.6 & $*$ & & $*$ \\
\hline
\end{tabular}

The number of most cell types reduces gradually in a mediolateral progression through the ELL. Stars indicate a significant difference between maps. $n$, number of fish. $N$ of the VML: neurons of the ventral molecular layer.

- The abundance of granule cells was estimated by camera lucida tracing of the granule cell area, followed by cutting out and weighing of the area.

cells were filled in lateral map injections, while only a single cell was found among the injections in each of the other 2 maps.

It is difficult to label pyramidal cells sufficiently by intracellular injections to be able to examine their terminal arborizations in the torus semicircularis, at a distance of $2 \mathrm{~mm}$ from the ELL. Pyramidal cell axons are unmyelinated and rather small $(<3 \mu \mathrm{m})$, and the large apical dendrites of these cells constitute an enormous sink for any label injected in the vicinity of the soma. Of the 34 intracellularly filled pyramidal cells, 14 (11 basilar and 3 nonbasilar pyramidal cells) were labeled sufficiently with Lucifer yellow to permit tracing of their terminal arborization in the torus semicircularis: 2 cells were from the lateral map, 7 from the centrolateral map, and 5 from the centromedial map. Camera lucida tracings of the terminal fields were conducted at $100 \times$ total magnification in order to reduce bleaching of the Lucifer yellow; the axonal arborizations were so fine, however, that in a number of cases they were too faint for complete tracing. Cells were considered to terminate in a specific lamina if the axon branched several times within the lamina. Pyramidal cells projected to more than one lamina and differed in their projection patterns to different laminae. As illustrated in Figure 7, 4 different projection patterns were seen: (1) projections to laminae $3,5,7,8 \mathrm{c}$, and/or $8 \mathrm{~d}$ (5 out of 14; examples in Fig. 7, $A, B, E$ ); (2) projections to laminae 3, 5, 7, $8 \mathrm{c}$, with bilateral projections in laminae 3 or 5 ( 1 out of 14 ; also seen in a case in which the location of the soma was unknown; example Fig. $7 E$ ), (3) projections to either laminae 3 or $5,7,8 \mathrm{c}$ (4 out of 14; example in Fig. $7 C$ ), and (4) projections to laminae 5 and $8 c$ or $8 d$ ( 4 out of 14 ; example in Fig. $7 F$ ). Of these 4 patterns, no map-specific differences were found, with the exception of the last pattern tending to be more prevalent in the centrolateral map. Of the 4 cells projecting solely to laminae 5 and $8 \mathrm{c} /$ or $8 \mathrm{~d}, 2$ were from the centrolateral map; 1 was on the centrolateral-lateral border; and 1 was from the centromedial map. This cell type may be the reason for the sparse projection to lamina 7 observed with extracellular injections in the centrolateral map. A larger sample size, however, is needed to uncover any statistical differences among maps.

The somatotopic representation of the body surface in the torus semicircularis maps the rostrocaudal body axis rostrocaudally and the dorsoventral body surface mediolaterally (Carr and Maler, 1986). The extent of arborization of pyramidal afferent terminal fields was measured in a few cases. The mediolateral range of terminal field sizes was $35-300 \mu \mathrm{m}$, while the rostrocaudal range was $100-300 \mu \mathrm{m}$. These numbers represent rough lower bounds of terminal field dimensions from the pyramidal efferents, since it was uncertain whether the full extent of each terminal field was traced completely.

The axons of all pyramidal efferents projected to the contralateral torus semicircularis. A few axons bifurcated in the lateral lemniscus, projecting bilaterally to the torus semicircularis. The extent of arborization of these latter cells was similar on both sides of the torus semicircularis. Collaterals of the pyramidal cell efferents projected to the contralateral nucleus praeeminentialis dorsalis. Much as in the case of the torus semicircularis projections, a few projected bilaterally.

A total of 5 HRP injections were made in the torus: 4 in lamina 5 and 1 in lamina 7. An additional 11 injections were available from a previous study: 4 injections were in laminae $8 \mathrm{c}$ and $8 \mathrm{~d} ; 3$ in laminae $8 \mathrm{~d}$ and $9 ; 3$ in lamina 7 ; and 1 in lamina 5 (Carr et al., 1981). In all cases, retrogradely labeled pyramidal cells were found in more than 1 map in the ELL, confirming the anterograde injections. Injections confined to lamina 7 produced heavy retrograde labeling of ampullary cells in the medial map.

\section{Levels of cytochrome oxidase activity}

Cytochrome oxidase studies in the visual system have identified areas which have subsequently been shown to be physiologically distinct, such as the blobs and nonblobs in visual area 17 of the cat cortex (see Livingstone and Hubel, 1987). Levels of cytochrome oxidase activity among tuberous maps were compared in 5 Eigenmannia, 2 Apteronotus, and 3 Hypopomus. Figures $8 A$ and $8 B$ show 2 examples of cytochrome oxidase activity in the maps in Eigenmannia, while Figures $8 C$ and $8 D$ show examples of the activity in Hypopomus and Apteronotus, respectively. As illustrated in Figure 8, the major difference among maps in all 3 species was an increased level of cytochrome oxidase activity in the dorsal molecular layer of the lateral map. Figure $8 D$ shows that Apteronotus differed from the other species in having a similar level of activity in the centrolateral map as well.

Differences in cytochrome oxidase activity were quantified by comparing the relative optical density of the dorsal molecular layer among maps from the same brain section (see Materials and Methods for further details). Measurements were made for each transverse section, and a minimum of 5 sections was 

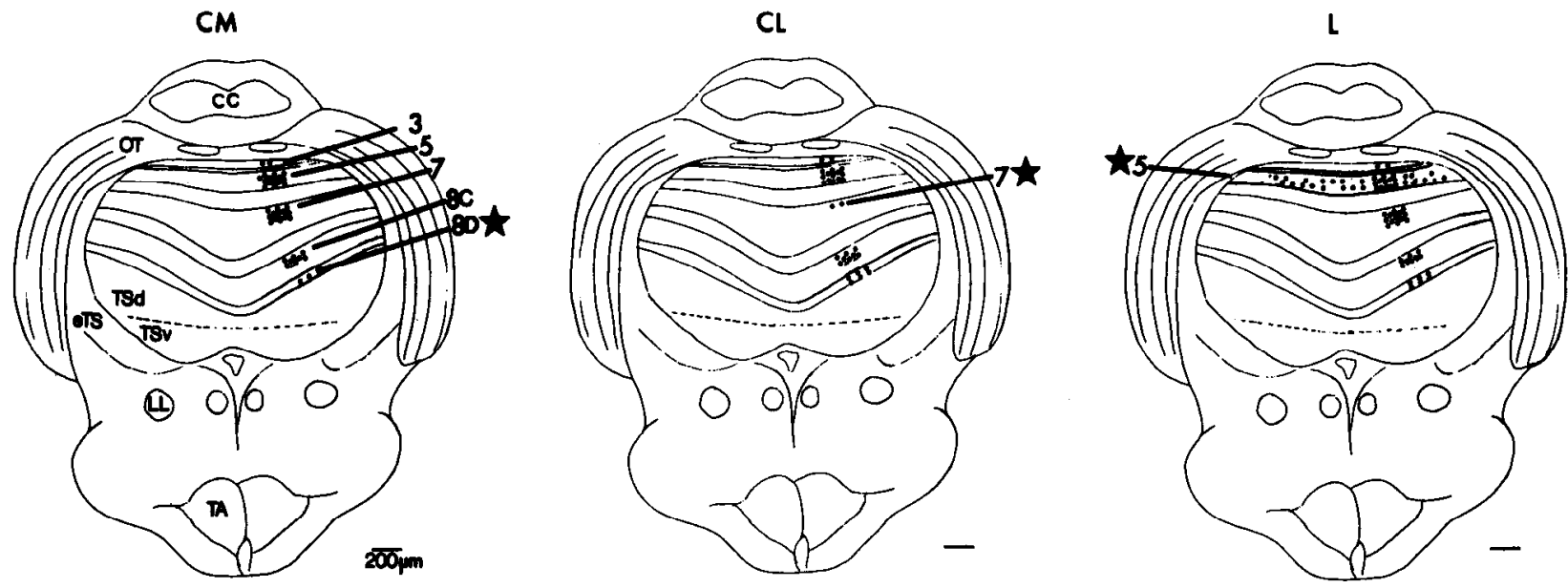

B
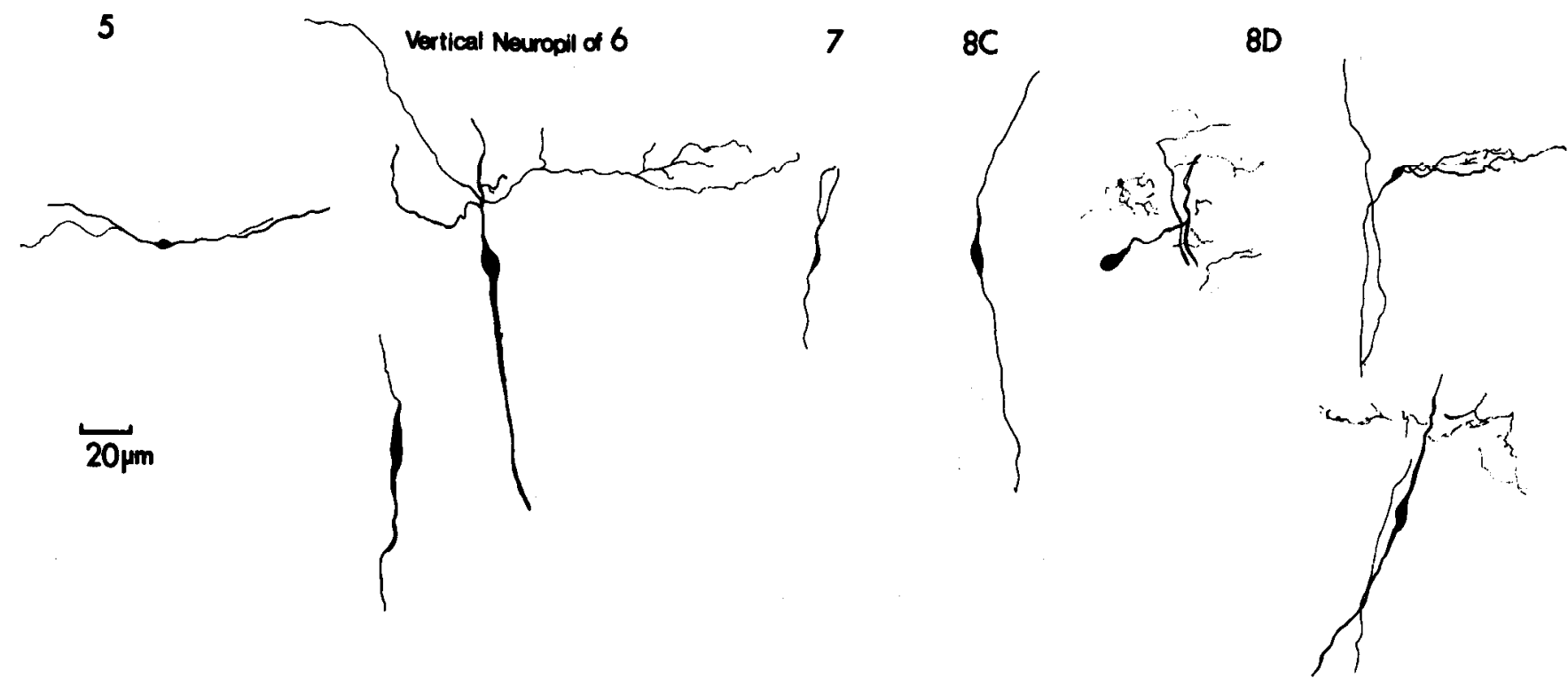

Figure 6. A, Summary charting of the efferent projections of pyramidal cells in the 3 ELL maps to the contralateral torus semicircularis in Eigenmannia. Similar, but weaker projections were often seen in the ipsilateral torus semicircularis. Dots represent major terminal arborizations. The main differences among maps are indicated by stars: cells in the centromedial map do not project heavily to lamina 8d; cells in the centrolateral map do not project heavily to lamina 7, and cells in the lateral map terminate throughout much of lamina 5 . Abbreviations: $C C$, corpus cerebelli; $L L$, lateral lemniscus; $O T$, optic tectum; $T S d$, dorsal torus semicircularis; $T S v$, ventral torus semicircularis; $T A$, nucleus tuberis anterior; $e T S$, torus semicircularis efferents. Scale bar, $200 \mu \mathrm{m}$. B. Examples of axonal varicosities from pyramidal cells of the lateral map, found in different laminae of the torus semicircularis (5-8d). Scale bar, $20 \mu \mathrm{m}$.

examined per fish. By this measure, the mean percent increase in cytochrome oxidase activity in the dorsal molecular layer of the lateral map, relative to that of the centromedial map, was $21 \pm 14 \%$ (SD) in Eigenmannia, $10 \pm 2 \%$ in Apteronotus, and $10 \pm 6 \%$ in Hypopomus. In the case of Apteronotus, the mean percent increase in cytochrome oxidase activity in the centrolateral map, relative to the centromedial map, was $8 \pm 4 \%$. Results were consistent across fish for all 3 species. Cytochrome oxidase activity was qualitatively examined in an additional wave-type species, Sternopygus $(n=2)$. Here, too, the dorsal molecular layer of the lateral map exhibited an increased level of cytochrome oxidase activity relative to the other maps (data not shown).
A sign test was conducted to compare cytochrome oxidase activity between maps from different sections of a single Apteronotus; this test provides a measure of the variability in activity within a single fish. Lateral map values were found to be significantly different from the centromedial map values $(n=8$ sections, $p<0.02$ ). The other species showed the same trend, but only 5 sections were generally available for lateral/centromedial comparisons, and this small number precluded statistical analyses. In the case of Eigenmannia. all 5 sections from 3 fish, and 4 out of 5 sections in the other 2 fish showed an increased level of activity in the dorsal molecular layer of the lateral map; measurements in the other 2 sections displayed no change in activity. 
(a)

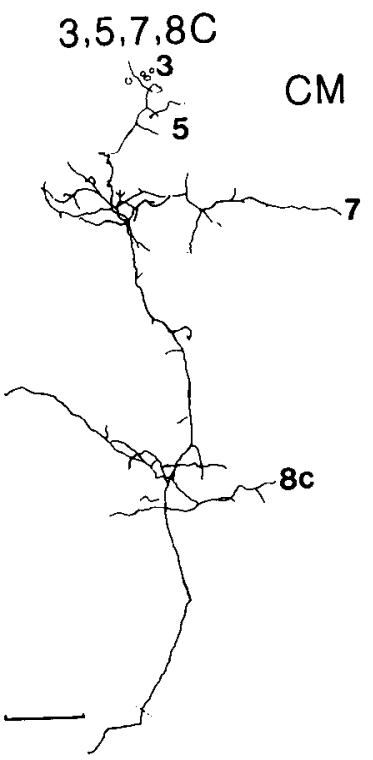

(D)

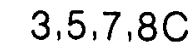

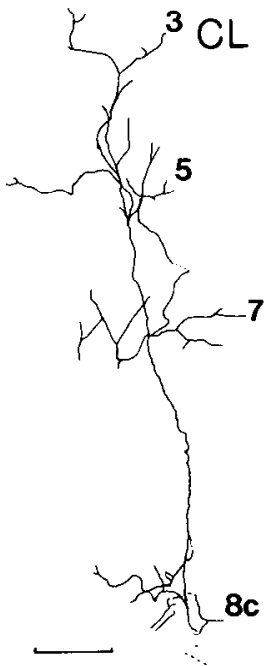

$3,5,7,8 \mathrm{C} ; \mathrm{BILAT}$. IN 3
(C)

$3,7,8 \mathrm{C}$

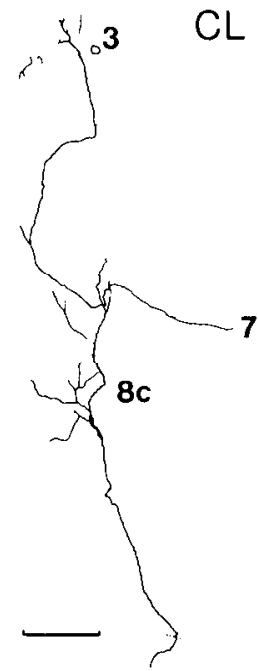

$5,8 \mathrm{C}$
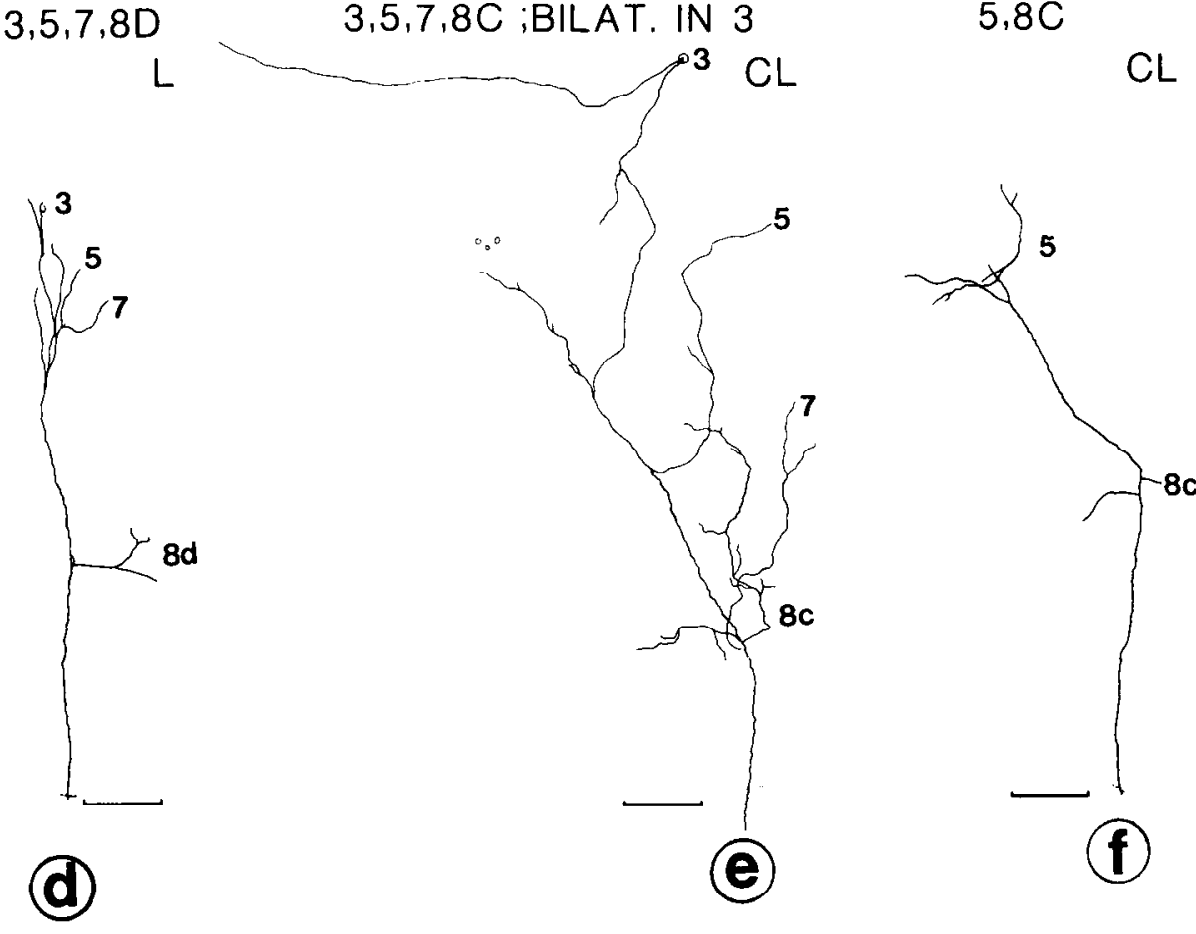

Figure 7 Camera lucida tracings of pyramidal-cell terminal fields in the torus semicircularis. The numbers above each tracing indicate the laminae in which the pyramidal-cell afferent terminated. Scale bar, $100 \mu \mathrm{m}$.

$\mathrm{CL}$

ences. The ELL of Apteronotus is very similar to that of Eigenmannia, both in cell types and relative cell numbers (Maler, 1979), and for this reason both species will be discussed jointly in the following sections. The results on pulse-type fish will be addressed separately, as less is known about their ELL circuitry. When possible, results from this study will be discussed in reference to the map-specific physiological differences described in the preceding paper (Shumway, 1989).

\section{Primary afferent input}

Previous research has shown that the 3 maps receive identical input from axonal collaterals of both phase- and amplitudecoding primary afferents (Carr et al., 1982; Heiligenberg and Dye, 1982). The results from the present study indicate that the 

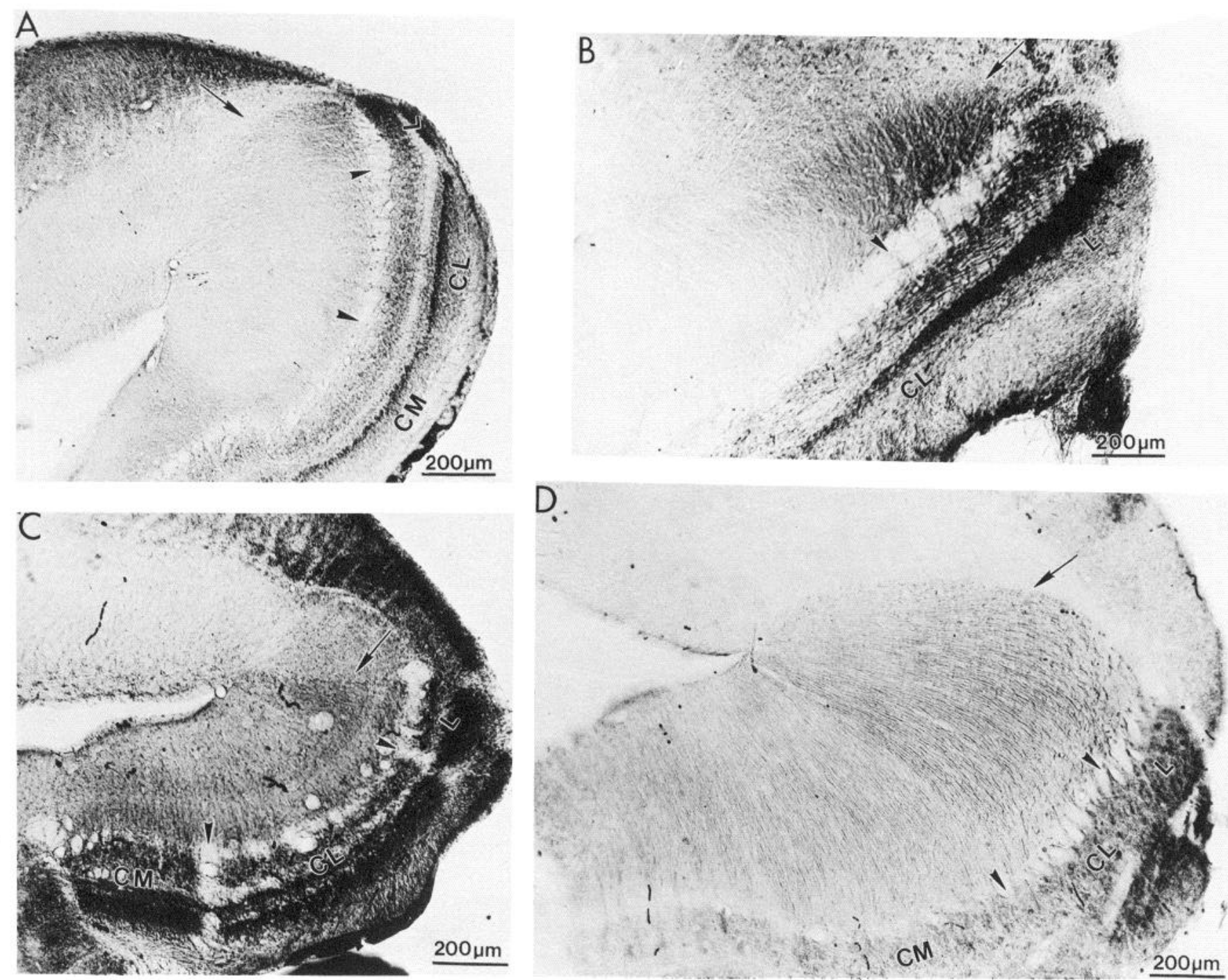

Figure 8. Transverse sections of the ELL from 3 different species, stained for cytochrome oxidase. A and B, Eigenmannia sp.; C, Hypopomus occidentalis; D, Apteronotus leptorhynchus. The main difference among maps in all three species is the greater level of cytochrome oxidase activity in the dorsal molecular layer of the lateral map (arrows). In Apteronotus, an increased level of activity is also found in the centrolateral map. Arrowheads indicate cytoarchitectonic breaks between maps. Scale bars, $200 \mu \mathrm{m}$.

terminal field sizes of the P-type primary afferents in Eigenmannia are the same in the 3 maps. The lateral map, however, is one-third the size of the centromedial map and has about one-half the number of cells. These results suggest that, given equal spacing between cells in the differently sized maps, cells in the lateral map receive a 2 - to 3 -fold greater convergence of primary afferent input than cells in the centromedial map. The spacing between pyramidal cell somata within each map was measured in a single fish ( $n=50$ cells); indeed, all maps showed a similar spacing of approximately $15 \mu \mathrm{m}$ between pyramidal cells.

One can estimate the number of primary afferents converging onto pyramidal cells in the different maps, based on the following background: Carr et al. (1982) showed that there are about 7600 primary afferent ganglion cells innervating $\mathrm{P}$ - and T-type tuberous receptors and ampullary receptors on one side of the body in Eigenmannia. A recent, more accurate measurement yielded a slightly lower value of 5700 (Vischer et al., 1989); some of the discrepancy is likely due to the use of fish of different sizes. Cell counts in Apteronotus suggest that 1 ganglion cell innervates 1 tuberous receptor (Carr et al., 1982, but see Vischer et al., 1989). [The number of ampullary receptors is so much lower, roughly 350 , that they can effectively be ignored (Carr et al., 1982; Vischer et al., 1989).] Zakon (1987) has also shown a 1:1 relationship between receptor organs and primary afferents in small Eigenmannia $(<8 \mathrm{~cm})$; larger fish of $10-16 \mathrm{~cm}$ length can have 1-7 receptor organs per afferent axon, but the greatest proportion of the receptor population (nearly $45 \%$ ) still shows the 1:1 relationship with ganglion cells. As there is no current anatomical method for distinguishing between P- and T-type primary afferents or receptors in Eigenmannia and Apteronotus (but see studies on Sternopygus by Sanchez and Zakon, 1986, 1989), the total number of ganglion cells from Vischer et al. and Carr et al. was used to estimate the lower and upper bounds of P-type receptor convergence, respectively. As basilar and nonbasilar pyramidal cells appear to receive input from the same patch of body surface (Maler, 1979), one can calculate the degree of convergence of P-type primary afferent input for each map by dividing the number of ganglion cells by one-half the total number of pyramidal cells. 


\begin{tabular}{|c|c|c|c|}
\hline \multirow[b]{2}{*}{ Anatomical property } & \multicolumn{3}{|l|}{ Map } \\
\hline & $\mathrm{CM}$ & $\mathrm{CL}$ & $\mathbf{L}$ \\
\hline Map area & Large & Medium & Small \\
\hline Number of output neurons & Highest & Middle & Few \\
\hline $\begin{array}{l}\text { Estimate of convergence (number of } P \\
\text { receptors onto a pyramidal cell) }\end{array}$ & $8-11$ & $10-13$ & $17-22$ \\
\hline $\begin{array}{l}\text { Relative occurrence of pyramidal cell } \\
\text { collaterals }(\%)\end{array}$ & 90 & 50 & 0 \\
\hline Number of $N$ of VML cells & 10 & 100 & 95 \\
\hline Cytochrome oxidase activity in DML & Low & Low & High \\
\hline Efferent projections to TS & Weak 8D & Weak 7 & Bilateral 5 \\
\hline
\end{tabular}

N of VML: neurons of the ventral molecular layer; DML; dorsal molecular layer; TS; torus semicircularis.

With these assumptions, I estimate that approximately 1722 receptors converge onto 1 pyramidal cell in the lateral map, 10-13 converge in the centrolateral map, and 8-11 converge in the centromedial map. These ranges are the lowest estimates of convergence, because afferents probably contact more than 1 pyramidal cell. Since the centromedial and lateral map sizes in Apteronotus also differ by a similar factor, a similar difference in convergence of afferent input is likely to be found in this species.

The mean receptive-field size of pyramidal cells in the centromedial and lateral maps of Eigenmannia differs by a factor of 2 (Shumway, 1989). The convergence of afferent input also differs by a similar factor, suggesting that receptive field differences among maps can largely be explained by differences in convergence. This does not rule out a possible role of descending input and local inhibition by granule cells in differential modulation of receptive-field sizes among maps. Bastian (1986a) has shown that lesions of the descending input from the EGp increase the receptive-field size of pyramidal cells in Apteronotus.

The threshold sensitivity of pyramidal cells to amplitude modulations differs by a factor of 3 between the lateral and centromedial maps in Eigenmannia; this is also likely to be the result of different degrees of convergence. The EGp does not appear to influence threshold sensitivity, since lesions of the EGp have no effect on thresholds of pyramidal cells (Bastian, 1986a).

What do we know about the convergence of T-type afferent input onto spherical cells? Like the amplitude-coding circuit in the ELL, terminal-field areas of T-type primary afferents are at least qualitatively similar among maps (C. A. Shumway, unpublished observations), and there are over 3 times more spherical cells in the centromedial map than in the lateral map (also see Carr et al., 1986). Measurements of the spacing between spherical cells in each map indicate, however, that spherical cell spacing differs among maps ( $n=50$ cells): cells in the lateral and centrolateral maps are approximately $50 \mu \mathrm{m}$ apart, while those in the centromedial map are only $20 \mu \mathrm{m}$ apart. This result suggests both a 3-fold greater convergence of T-type afferent input onto the few cells in the lateral map and a nearly 3-fold greater divergence of afferent input onto the many cells in the centromedial map, as the same-sized afferent terminal field can reach 2.5 times more spherical cells. The centromedial map, therefore, should have more cells devoted to processing phase information from the same region of the body than the lateral map. It would be very interesting to compare the synaptic or- ganization of spherical cell terminal fields from the different ELL maps in the torus semicircularis.

\section{Local circuitry}

The ratio of pyramidal neurons to most interneurons (except the neuron of the ventral molecular layer) did not change among maps, suggesting that the general circuitry within maps is similar, at least at the light-microscopic level. Critical experiments for greater understanding of the circuitry within maps are comparisons of cell morphologies among maps with Golgi-stained material and examination of the synaptic properties (both number of synapses and their relative position) of pyramidal cells among maps. In particular, it will be most important to compare the number and location of synapses from granule cell types 1 and 2 among maps. Granule cells of type 1 are non-GABAergic, while those of type 2 are GABAergic (Maler and Mugnaini, 1986). Recent work suggests that the spatial and temporal response properties of pyramidal cells are largely independently controlled by these 2 types of interneurons containing different neurotransmitters; the activity of these cells in turn is regulated by descending input (Bastian, 1986a, b; Shumway and Maler, 1989).

Three anatomical results, however, reflect presumable differences in processing among maps: differences in cytochrome oxidase activity in the dorsal molecular layer, differences in the number of neurons of the ventral molecular layer, and differences in the occurrence of local axonal collaterals of pyramidal cells. The first 2 results reflect differences in the descending feedback circuits. The functional significance of axonal collaterals is unknown.

The increased level of cytochrome oxidase activity in the dorsal molecular layer of the lateral map in Eigenmannia and Apteronotus indicates increased metabolic activity in this layer. Apteronotus differed from Eigenmannia in having a similar level of activity in the dorsal molecular layer of the centrolateral map as well. This difference between species is intriguing, but its functional significance remains unclear. Cytochrome oxidase studies in other systems suggest a positive correlation between the amount of cytochrome oxidase activity and the amount of excitatory input (Kageyama and Wong-Riley, 1986). Thus, the lateral map in Eigenmannia, and both lateral and centrolateral maps in Apteronotus may receive elevated amounts of excitatory descending input from the EGp; whether this reflects greater activity at each synapse or a higher density of synapses relative to the other maps is unknown but testable. Bastian (1986a) has 
shown that the predominant influence of the (excitatory) descending projection from the EGp on pyramidal cells is inhibitory, acting via inhibitory interneurons in the ELL. The lateral map in Eigenmannia, therefore, may receive more inhibition from the EGp descending pathway than the other 2 maps.

The cytochrome oxidase results suggest that descending input from the EGp is map-specific. How does such specificity arise? Large HRP injections in the EGp suggest a single body map of tuberous receptor input, but the representation of the dorsoventral body axis in the EGp is still unclear (Sas and Maler, 1987) and awaits reexamination with smaller HRP injections as well as physiological studies of the EGp.

Pyramidal cells differ among maps in their rate of adaptation to a step change in amplitude, with lateral map units being most phasic, and centromedial units least phasic (Shumway, 1989). Descending input from the EGp has been shown to regulate the phasic properties of pyramidal cells; lesions of the EGp make pyramidal cells more tonic (Bastian, 1986a). Experiments with bicuculline, a GABA-A antagonist, suggest that control of the rate of adaptation by the descending input is mediated through GABAergic interneurons, primarily granule cell type 2, along with neurons of the ventral molccular layer (Shumway and Maler, 1989). Results from the present study suggest that the bases for different rates of adaptation among maps may be different levels of inhibition mediated by descending input: the cytochrome oxidase results provide suggestive evidence for increased inhibition in the lateral map. Suggestive evidence for decreased inhibition in the centromedial map is that this map contains fewer neurons of the ventral molecular layer than the other maps; since neurons of the ventral molecular layer inhibit pyramidal cells, their reduced density in the centromedial map could partially account for the more tonic response of its pyramidal cells. Preliminary experiments with GAD, the synthesizing enzyme for GABA, provide further support for decreased inhibition in the centromedial map. This map appears to have the least amount of GABAergic boutons in the pyramidal cell layer relative to the other maps (C. A. Shumway, and W. Heiligenberg, unpublished observations).

The 3 zones in the NPd which project to the ELL have been shown to differ in cell types, number, and size (Maler et al., 1982; Sas and Maler, 1983). These anatomical differences may reflect physiological differences among the 3 NPd zones; the response properties of cells in the nucleus praeeminentialis are currently being explored (Bastian and Bratton, 1988, 1989). Perhaps one function of the descending input from the NPd is the generation of different temporal-frequency responses among maps in the ELL. The EGP is less likely to be involved, since lesions of the EGp have no effect on the temporal-frequency response of pyramidal cells (Bastian, 1986a). Given the apparent similarity in local circuitry among ELL maps at the light-microscopic level, this is at least the simplest hypothesis about generation of temporal-frequency responses and could easily be tested with lesions of the nucleus praeeminentialis.

\section{Efferent projections to the torus semicircularis}

The results in this study indicate convergence of pyramidal cell efferents from the 3 ELL maps to at least the same laminae in the torus semicircularis, corroborating earlier work by Carr et al. (1981) and Maler et al. (1982). Previous studies of singlylabeled pyramidal efferents to the torus semicircularis had demonstrated the projection patterns of a few pyramidal cells. These injections were too weak, however, to determine the location of their somata in a specific map (Saunders and Bastian, 1984; Heiligenberg and Rose, 1985).

This study has demonstrated that the strength of pyramidal efferent projections to a given lamina differs among maps. Carr et al. $(1981,1986)$ and Carr and Maler (1985) have emphasized the rich potential for parallel and hierarchical processing in the torus semicircularis. This structure contains 12 laminae and 48 different cell types, at least 17 of which have dendritic projections to laminae receiving ELL afferents. Some cells appear to integrate information across several laminae, while others have horizontal dendrites receiving input throughout a single lamina (Carr and Maler, 1985). Physiological studies have demonstrated that many neurons in laminae 5 and 7 are only sensitive to amplitude modulations, while many neurons in the deeper layers are sensitive to combinations of amplitude and phase modulations (Heiligenberg and Rose, 1985; Rose and Heiligenberg, 1985). Torus efferents project to at least 6 major targets, and almost all layers contain efferent cell types (Carr et al., 1981).

Given such complexity in the torus semicircularis and the fact that the strength of pyramidal efferent projections differs among maps, it is likely that the efferents from the 3 maps differ in their synaptic targets within laminae, perhaps projecting to different cells or to different synaptic regions of the same cells. This issue awaits electron-microscopic examination of the amplitude-processing laminae in the torus semicircularis. In addition, as the receptive-field sizes of pyramidal cells in the 3 maps differ, one would expect their terminal arborizations in the torus semicircularis to differ correspondingly in extent; this is necessary in order to maintain a precise somatotopy in the torus semicircularis.

\section{Pulse-type species}

Pulse-type gymnotiform fish have 2 anatomically and physiologically distinct subtypes of tuberous receptors serving functions presumably similar to those in wave-type fish. These receptors are the phase-coding pulse markers, which fire 1 spike per EOD pulse, and the amplitude-coding burst-duration codcrs, which encode the signal amplitude by the number of spikes in a burst (see Zakon, 1986, for review). Although the anatomy and physiology of the ELL in pulse-type fish are not as well known as in wave-type species, numerous similarities abound between both groups. Similar cell types include basilar pyramidal cells, spherical cells (termed "pear-shaped neurons" by Réthelyi and Szabo, 1973), granule cells types 1 and 2, and multipolar cells. Schlegel (1973) has shown that pyramidal cells in the ELL of pulse-type fish respond to moving metal and plastic objects in different regions of their receptive field, suggesting the presence of center-surround organization, as has been demonstrated in wave-type fish (Shumway, 1989). Furthermore, Schlegel's results indicate that pyramidal cells in pulsetype fish are phasic, show postexcitatory rebound responses, increase their response with increasing temporal frequencies, and are directionally selective in some cases. The remarkable similarities in responses of pyramidal neurons in these 2 types of gymnotiform fish suggest that the basic amplitude-coding circuit in the ELL of pulse-type fish is similar to that of wavetype species. Other cell types known to occur in the ELL of wave-type gymnotiform fish have not yet been described in pulse-type species.

The size of the centromedial map in pulse-type fish of the family Hypopomidae, like that of wave-type fish, is nearly twice as large as the size of the lateral map. The area of the centro- 
lateral map, however, is even greater, being roughly 3.5 times as large as that of the lateral map. One would predict, then, that the greatest difference in receptive-field size of pyramidal neurons in Hypopomus would be found between the centrolateral and lateral maps. Cytochrome oxidase studies indicate that the lateral map in Hypopomus, like that in wave-type fish, has an increased level of cytochrome oxidase activity in the dorsal molecular layer. This result suggests that the unique processing of descending information in the lateral map is a characteristic common to both groups of fish.

\section{Similarities with other systems}

The afferent and efferent characteristics of the multiple maps in the ELL are similar to those found in mammalian sensory systems. First, axonal bi- and trifurcation is common in the visual system of cats and monkeys, from retinal ganglion cell projections to corticocortical projections (Birnbacher and Albus, 1987; for review, see Bullier and Kennedy, 1987). Estimates of the percentage of neurons with bifurcating axons range from 10 to $30 \%$ at different levels. Axonal bifurcation also occurs in somatosensory and auditory thalamocortical projections (Spreafico et al., 1981; Morel and Imig, 1987). Second, although efferent projections of multiple cortical sensory areas overlap in many cases, they are nonetheless unique, both in the strength of their projections and in the different targets to which they project (see reviews by Jones and Porter, 1980; Kaas, 1983; Brugge and Reale, 1985; Rosenquist, 1985; Van Essen, 1985).

\section{Why are there multiple maps in the ELL?}

Physiological experiments have suggested that at least 2 and perhaps 3 distinct classes of pyramidal cells are located in different maps of the ELL (Shumway, 1989). The 2 distinct classes are found in the centromedial and the lateral maps, while cells in the centrolateral map have properties intermediate to those of the other 2 maps. Why are these classes not accommodated within a single map? As suggested by Kaas (1982) and Barlow (1986), among others, multiple maps may be important in sensory processing because the number of different functions that can be executed within any one map may be limited. Each function is dependent on local circuit interactions which require that the neurons be spaced closely together. A likely anatomical constraint is the maximum extent of dendritic fields. The number of new functions that can be added to any given area while still maintaining somatotopic organization will, therefore, be limited by the effective dendritic range of the local circuit. The dendritic interactions of pyramidal cells with other neurons in the ELL are highly laminar-specific, with precise segregation of afferent input, descending input, and interneuronal input onto different parts of the basilar and nonbasilar pyramidal cell dendrites (Maler, 1979; Maler et al., 1981). These local interactions are important in the general physiological transformations that take place at the level of the ELL in all maps, such as generation of phasic responses, center-surround receptive-field organization, and creation of E- and I-type responses to step changes in amplitude, and the importance of these specific local interactions for early electrosensory processing may be the reason for the multiplicity in electrosensory representation. The differences in electrosensory processing among maps could then be caused by reformulation of the existing circuits.

An additional reason for having multiple sensory areas, as suggested by Allman and Kaas (1971), is that to change an existing neuronal circuit in order to accommodate new functions may imperil an animal's survival. Allman and Kaas have emphasized that duplication of a neuronal structure allows the original structure to perform its necessary function and frees the duplicated structure from pressures of natural selection, thus providing an optimal environment for genetic change. The parccllation theory of Ebbesson (1980) states that most evolutionary changes in the vertebrate nervous system are the result of such differentiation of existing neuronal circuits rather than the creation of circuits de novo. Indeed, replication of body parts with subsequent differentiation is a common process throughout evolution (Gregory, 1935).

\section{References}

Allman, J. M., and J. H. Kaas (1971) A representation of the visual field in the caudal third of the middle temporal gyrus of the owl monkey (Aotus trivirgatus). Brain Res. 31: 84-105.

Barlow, H. B. (1986) Why have multiple cortical areas? Vision Res. 26: $81-90$.

Bastian, J. (1986a) Gain control in the electrosensory system mediated by descending inputs to the electrosensory lateral line lobe. J. Neurosci. 6: $553-562$.

Bastian, J. (1986b) Gain control in the electrosensory system: A role for the descending projections to the electrosensory lateral line lobe. J. Comp. Physiol. 158: 505-515.

Bastian, J., and B. O. Bratton (1988) The nucleus praeeminentialis: Properties of neurons providing descending inputs to the electrosensory lateral line lobe of weakly electric fish. Soc. Neurosci. Abstr. 14: 311.

Birnbacher, D., and K. Albus (1987) Divergence of single axons in afferent projections to the cat's visual cortical areas 17, 18, and 19: A parametric study. J. Comp. Neurol. 261: 543-561.

Brugge, J. F., and R. A. Reale (1985) Auditory cortex. In Cerebral Cortex, Vol. 4: Association and Auditory Cortices, A. Peters and E. G. Jones, eds., pp. 229-271, Plenum, New York.

Bullier, J., and H. Kennedy (1987) Axonal bifurcation in the visual system. Trends Neurosci. 10: 205-210.

Calford, M. B., M. L. Graydon, M. F. Huerta, J. H. Kaas, and J. D. Pettigrew (1985) A variant of the mammalian somatotopic map in a bat. Nature 313: 477-479.

Carr, C., and L. Maler (1985) A Golgi study of the cell types of the dorsal torus semicircularis of the electric fish Eigenmannia: Functional and morphological diversity in the midbrain. J. Comp. Neurol. 235: 207-240.

Carr, C., and L. Maler (1986) Electroreception in gymnotiform fish: Central anatomy and physiology. In Electroreception, T. H. Bullock and W. Heiligenberg, eds., pp. 319-373, Wiley, New York.

Carr, C. E., L. Maler, W. Heiligenberg, and E. Sas (1981) Laminar organization of the afferent and efferent systems of the torus semicircularis of gymnotiform fish: Morphological substrates for parallel processing in the electrosensory system. J. Comp. Neurol. 203: 649670.

Carr, C., L. Maler, and E. Sas (1982) Peripheral organization and central projections of the electrosensory nerves in gymnotiform fish. J. Comp. Neurol. 211: 139-153.

Carr, C., W. Heiligenberg, and G. J. Rose (1986) A time-comparison circuit in the electric fish midbrain. I. Behavior and physiology. J. Neurosci. 6: 107-119.

Ebbesson, S. (1980) The parcellation theory and its relation to interspecific variability in brain organization, evolutionary and ontogenetic development, and neuronal plasticity. Cell Tissue Res. 213: 179212.

Frank, K., and M. C. Becker (1964) Microelectrodes for recording and stimulation. In Physical Techniques in Biological Research, Vol. 5, Part A, W. L. Nastuk, ed., pp. 23-84, Academic, New York.

Gould, H. J., III (1986) Body surface maps in the somatosensory cortex of rabbit. J. Comp. Neurol. 243: 207-233.

Gregory, W. K. (1935) Reduplication in evolution. Q. Rev. Biol. 10: 272-290.

Heiligenberg, W. (1986) Jamming avoidances responses: Model systems for neuroethology. In Electroreception. T. H. Bullock and W. Heiligenberg, eds., pp. 613-649, Wiley, New York.

Heiligenberg, W., and J. Dye (1982) Labelling of electroreceptive af- 
ferents in a gymnotoid fish by intracellular injection of HRP: The mystery of multiple maps. J. Comp. Physiol. 148: 287-296.

Heiligenberg, W., and G. Rose (1985) Phase and amplitude computations in the midbrain of an electric fish: Intracellular studies of neurons participating in the jamming avoidance response of Eigenmannia. J. Neurosci. 5: 515-531.

Jones, E. G., and R. Porter (1980) What is area 3a? Brain Res. Rev. 2: $1-43$.

Kaas, J. H. (1982) The segregation of function in the nervous system: Why do sensory systems have so many subdivisions? In Contributions to Sensory Physiology, Vol. 7, W. P. Neff, ed., pp. 201-240, Academic, New York.

Kaas, J. H. (1983) What, if anything, is S1? Organization of first somatosensory area of cortex. Physiol. Rev. 63: 206-231.

Kageyama, G. H., and M. Wong-Riley (1986) Laminar and cellular localization of cytochrome oxidase in the cat striate cortex. J. Comp. Neurol. 245: 137-159.

Konigsmark, B. W. (1970) Methods for the counting of neurons. In Contemporary Research Methods in Neuroanatomy, W. J. H. Nauta and S. O. E. Ebbesson, eds., pp. 315-330, Springer-Verlag, New York.

Livingstone, M. S., and D. H. Hubel (1987) Connections between layer 4B of area 17 and the thick cytochrome oxidase stripes of area 18 in the squirrel monkey. J. Neurosci. 7: 3371-3377.

Maler, L. (1979) The posterior lateral line lobe of certain gymnotoid fish: Quantitative light microscopy. J. Comp. Neurol. 183: 323-364.

Maler, L., and E. Mugnaini (1986) Immunohistochemical identification of GABAergic synapses in the electrosensory lateral line lobe of a weakly electric fish (Apteronotus leptorhynchus). Soc. Neurosci. Abstr. 12: 312 .

Maler, L., E. Sas, and J. Rogers (1981) The cytology of the posterior lateral line lobe of high frequency electric fish (Gymnotidae): Dendritic differentiation and synaptic specificity in a simple cortex. $\mathrm{J}$. Comp. Neurol. 158: 87-141.

Maler, L., E. Sas, C. Carr, and J. Matsubara (1982) Efferent projections of the posterior lateral line lobe in gymnotiform fish. J. Comp. Neurol. 211: 154-164.

Metcalfe, W. K. (1985) Sensory neuron growth cones comigrate with postcrior lateral line lobe primordial cells in zebrafish. J. Comp. Neurol. 238: 218-224.

Morel, A., and T. J. Imig (1987) Thalamic projections to fields A, AI, $P$, and VP in the cat auditory cortex. J. Comp. Neurol. 265: 119144.

Pubols, B. H., L. M. Pubols, D. J. DiPette, and J. C. Sheely (1976) Opossum somatic sensory cortex: A microelectrode mapping study. J. Comp. Neurol. 165: 229-245.

Réthelyi, M., and T. Szabo (1973) Neurohistological analysis of the lateral lobe in a weakly electric fish, Gymnotus carapo (Gymnotidae, Pisces). Exp. Brain Res. 18: 323-339.

Rose, G., and W. Heiligenberg (1985) Structure and function of electrosensory neurons in the torus semicircularis of Eigenmannia: Morphological correlates of phase and amplitude sensitivity. J. Neurosci. 5: 2269-2280.

Rosenquist, A. (1985) Connections of visual cortex. In Cerebral Cortex, Vol. 3: Visual Cortex, A. Peters and E. G. Jones, eds., pp. 81117, Plenum, New York.

Sanchez, D. Y., and H. H. Zakon (1986) Neural correlates of cell addition in the electrosensory system. Soc. Neurosci. Abstr. 12: 313.
Sanchez, D. Y., and H. H. Zakon (1989) The effects of postembryonic receptor cell addition on the response properties of electroreceptive afferents (in press).

Sas, E., and L. Maler (1983) The nucleus praeeminentialis: A Golgi study of a feedback center in the electrosensory system of gymnotid fish. J. Comp. Neurol. 221: 127-144.

Sas, E., and L. Maler (1987) The organization of afferent input to the caudal lobe of the cerebellum of the gymnotid fish Apteronotus leptorhynchus. Anat. Embryol. 177: 55-79.

Saunders, J., and J. Bastian (1984) The physiology and morphology of two types of electrosensory neurons in the weakly electric fish Apteronotus leptorhynchus. J. Comp. Physiol. 154: 199-209.

Scheich, H., and S. E. Ebbesson (1983) Multimodal torus in the weakly electric fish Eigenmannia. Adv. Anat. Embryol. Cell Biol. 82: 1-40.

Schlegel, P. A. (1973) Perception of objects in weakly electric fish Gymnotus carapo as studied in recordings from rhombencephalic neurons. Exp. Brain Res. 18: 340-354.

Shumway, C. (1984) Efferent connections of the electrosensory lateral line lobe: An intracellular HRP and Lucifer study. Soc. Neurosci. Abstr. 10: 403.

Shumway, C. (1989) Multiple electrosensory maps in the medulla of weakly electric gymnotiform fish. I. Physiological differences. J. Neurosci. 9: 4388-4399.

Shumway, C., and L. Maler (1987) Bicuculline affects both temporal and receptive field properties of pyramidal cells in the electrosensory lateral line lobe. Soc. Neurosci. Abstr. 13: 622

Shumway, C., and L. Maler (1989) GABAergic inhibition shapes temporal and spatial response properties of pyramidal cells in the electrosensory lateral line lobe of gymnotiform fish. J. Comp. Physiol. 164: 391-407.

Shumway, C., and R. Zelick (1988) Sex recognition and neuronal coding of electric organ discharge waveform in the pulse-type weakly electric fish, Hypopomus occidentalis. J. Comp. Physiol. 163: 465478.

Spreafico, R., N. L. Hayes, and Rustioni (1981) Thalamic projections to the primary and secondary somatosensory cortices in cat single and double retrograde tracer studies. J. Comp. Neurol. 203: 67-90.

Sur, M., R. J. Nelson, and J. H. Kaas (1982) Representations of the body surface in cortical areas $3 \mathrm{~b}$ and 1 of squirrel monkeys: Comparisons with other primates. J. Comp. Neurol. 211: 177-192.

Van Essen, D. C. (1985) Functional organization of primate visual cortex. In Cerebral Cortex, Vol. 3: Visual Cortex, A. Peters and E. G. Jones, eds., pp. 259-329, Plenum, New York.

Vischer, H. A., M. J. Lannoo, and W. Heiligenberg (1989) The development of the electrosensory nervous system in Eigenmannia (Gymnotiformes): I. The peripheral nervous system. J. Comp. Neurol. (in press).

Wong-Riley, M. (1979) Changes in the visual system of monocularly sutured or enucleated cats demonstrable with cytochrome oxidase histochemistry. Brain Res. 171: 11-28.

Zakon, H. H. (1986) The electroreceptive periphery. In Electroreception, T. H. Bullock and W. Heiligenberg, eds., pp. 103-156, Wiley, New York.

Zakon, H. H. (1987) Variation in the mode of receptor cell addition in the electrosensory system of gymnotiform fish. J. Comp. Neurol. 262: 195-214. 